\title{
Seismic performance assessment based on the interstory drift of steel buildings
}

\section{Diego Arcos Díaz ${ }^{a}$ (D), Sergio A. Diaz ${ }^{a^{*}}$ (D) , Luis A. Pinzón ${ }^{b}$ (D), Hiram Jesús ${ }^{c}$ (D), Rene S. Mora-Ortiz}

aDivisión Académica de Ingeniería y Arquitectura, Universidad Juárez Autónoma de Tabasco, México. E-mails: arcosd.diego97@gmail.com; alberto.diaz@ujat.mx; rene.mora@ujat.mx

bDirección de Investigación, Universidad Católica Santa María La Antigua, Ciudad de Panamá, Panamá. Email: Ipinzon@usma.ac.pa cUniversidad Autónoma del Carmen, Campeche, México. Email: hjesus@delfin.unacar.mx

* Corresponding author

https://doi.org/10.1590/1679-78256583

\begin{abstract}
The seismic regulations for the seismic performance assessment of buildings use the maximum interstory drift, $\theta_{\max }$ as a measure to control damage. This article presents a study of the seismic performance based on the $\theta_{\max }$ for steel buildings using Mexico's regulations and the RISK-UE and HAZUS guidelines. The capacity spectrum method is used to evaluate the performance of buildings with 3 different heights located in 4 cities in Mexico with different seismicity, as well as for soft and rock soil types. The HAZUS criterion is conservative in its assement of damage, while the RISK-UE criterion is more in line with the expected damage. The service state, $\mathrm{S}_{\text {state, }}$ and the collapse prevention state, $\mathrm{CP}_{\text {state, }}$ in Mexico's regulations are suitable for damage control, and are consistent with the damage proposed by the RISK-UE guidelines. In very high seismicity zones, the $\mathrm{CP}_{\text {state }}$ for seismic actions equal to or greater than the expected, prevent building collapse; however, significant damage to buildings can still occur. The $\theta_{\max }$ of the $\mathrm{CP}_{\text {state }}$ must be established for different seismic intensities and not only for building types.
\end{abstract}

\section{Keywords}

Interstory drift, steel buildings, nonlinear static analysis, capacity spectrum, damage states

\section{Graphical Abstract}

$\theta_{i}=\frac{\delta_{i}-\delta_{i-1}}{h_{i}-h_{i-1}}, i=1 \ldots n \quad \theta_{\max }=\operatorname{Max}\left|\theta_{i} \ldots \theta_{n}\right|$
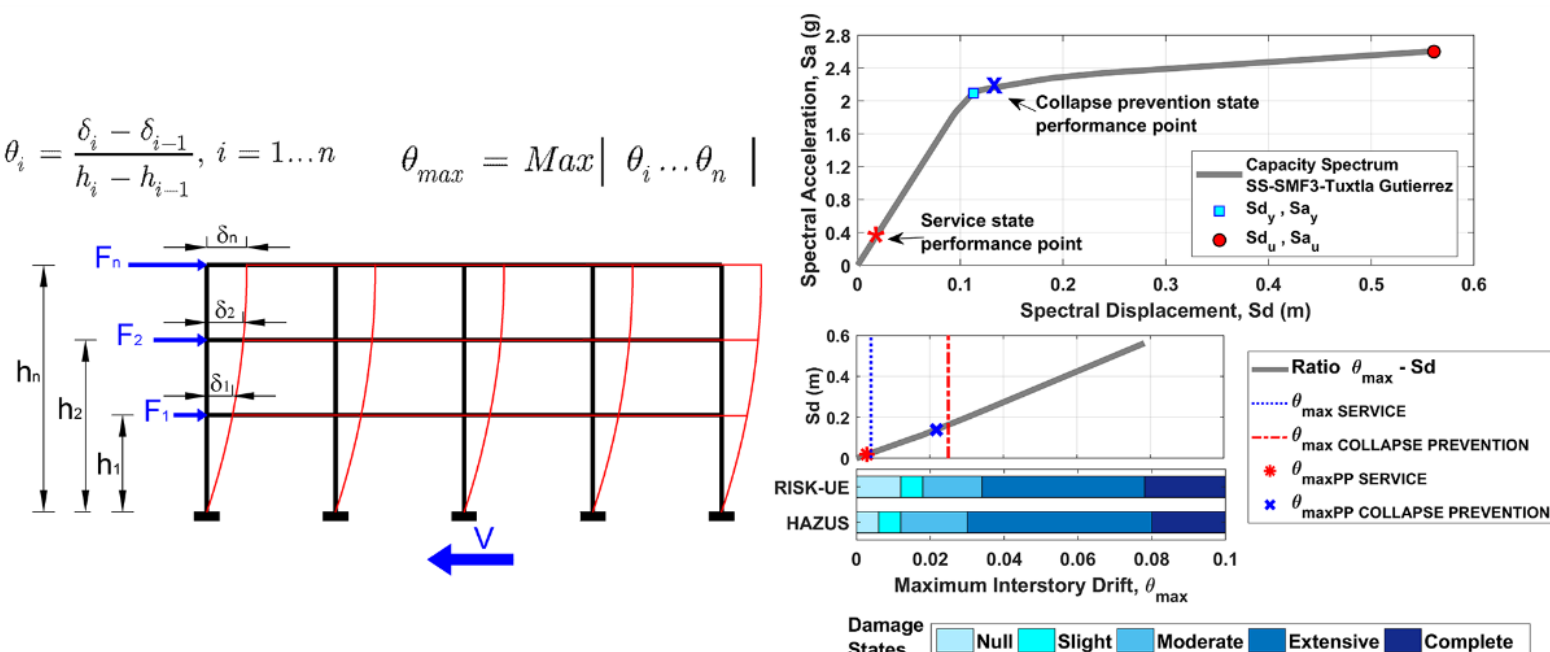

Received June 04, 2021. In revised form January 05, 2022. Accepted Month January 27, 2022. Available online January 28,2022 https://doi.org/10.1590/1679-78256583

(a) Latin American Journal of Solids and Structures. ISSN 1679-7825. Copyright (C) 2021. This is an Open Access article distributed under the terms of the Creative Commons Attribution License, which permits unrestricted use, distribution, and reproduction in any medium, provided the original work is properly cited. 


\section{INTRODUCTION}

The constant seismic activity throughout history has revealed a direct relationship between lateral displacements and the level of structural and non-structural damage in buildings (Andrade, 2004). Current regulations such as ASCE 716 in the United States (ASCE/SEI 7-16, 2016), the Manual for the Design of Civil Works by the Federal Electricity Commission of Mexico (MDOC-CFE, 2015), the Complementary Technical Standard of Mexico City (NTCDS-RCDF, 2017), Eurocode 8 (CEN, 2004), among others, propose limiting the quotient of the maximum difference between the lateral displacements of consecutive floors produced by seismic forces and the height of the story to achieve damage control; this value is called the "lateral distortion" or "interstory drift," $\theta_{\text {max. }}$ In this way, the current regulations establish permissible values of $\theta_{\max }$ depending on the type of structural system of the building for the service condition and collapse prevention condition.

In recent decades, nonlinear static analysis (NLSA) has made it possible to easily evaluate the structural performance of buildings subjected to lateral loads, such as those originating from earthquakes. The results of the NLSA have been shown to be very consistent with the behavior obtained with dynamic nonlinear analysis (NLDA) based on incremental dynamic analysis (IDA) (Vamvatsikos and Cornell 2002) of buildings subjected to seismic actions; in particular, the structural response of an analyzed building is dominated by the fundamental mode of vibration (Diaz et al. 2018a). The lateral thrust loads on the NLSA increase until the building collapses (Vargas et al. 2013). From this incremental push, when the structure enters the inelastic range, the structural elements are damaged by forming "plastic hinges." With the NLSA results, the capacity curve or pushover can be obtained, which relates the roof displacement, $\delta$, and the base shear, V. In the NLSA, the displacement on the roof of the structure is obtained for each load increase; therefore, it is possible to monitor the nodal displacements of each story and thus obtain the corresponding maximum interstory drift $\theta_{\text {max. }}$

Assuming that the structural response of a building is dominated by its first vibration mode, it is possible to convert the capacity curve to a "capacity spectrum" (CS) (ATC-40, 1996), which is related to the spectral acceleration, Sa, and spectral displacement, $\mathrm{Sd}$. The spectral displacement is obtained from the roof displacement, $\delta$, and $\mathrm{PF}_{1}$, the modal participation factor of the first vibration mode or fundamental period, $T_{1}$, of the building: $S d=\delta / P F_{1}$. The $s p e c t r a l$ acceleration was obtained from Sa $=\mathrm{V} /\left(\mathrm{W}^{\prime} \alpha_{1}\right)$, where $\mathrm{V}$ is the base shear, $\mathrm{W}$ is the weight of the structure, and $\alpha_{1}$ is the coefficient of participation of the modal mass of the first vibration mode. Generally, Sa is given as a fraction of gravity, $g$. Examples of $\mathrm{PF}_{1}$ and $\alpha_{1}$ calculations are given in ATC-40 (1996).

The advantage of using the capacity spectrum is that because of its Sa-Sd format, it can be linked to the seismic demand of a response spectrum or design spectrum, which is given in the spectral acceleration (Sa) format, such as ordinates, and structural period $(T)$ as abscissa. The structural period can be converted to spectral displacement using the following equation: $\mathrm{Sd}=9.81^{\prime} \mathrm{Sa}\left(\mathrm{T} 2 / 4 \pi^{2}\right)$. As the capacity and demand spectra are in the same format, it is possible to apply different techniques to obtain the performance point of a structure for a specific seismic action. Currently, some of the most used techniques are the capacity spectrum method (ATC, 1996, Freeman S.A., 1998), constant ductility method (Chopra and Goel, 1999, 2002; Fajfar, 2000), and energy balance method (EBC) (Mezzi et al. 2006; Leelataviwat et al. 2009).

The RISK-UE project (Milutinovic and Trendafiloski, 2003) proposes a bilinear adjustment of the capacity spectrum, in which the spectrum is defined by only two points: the first corresponds to the coordinate of the yield point ( $\mathrm{Sd}_{\mathrm{y}}$, $\left.\mathrm{Sa}_{\mathrm{y}}\right)$ and the second corresponds to the ultimate capacity point ( $\mathrm{Sd}_{\mathrm{u}}, \mathrm{Sa}_{\mathrm{u}}$ ). In RISK-UE (Milutinovic and Trendafiloski, 2003) and Diaz et al. (2017), a procedure for obtaining both points is presented in detail. Based on the spectral displacements of both points, the RISK-UE project defines four damage states $\left(\mathrm{Sd}_{\mathrm{i}}\right)$ : Slight, Moderate, Extensive, and Complete, using the following equations: $\mathrm{Sd}_{1}$ (Slight) $=0.7 \mathrm{Sd}_{\mathrm{y}} ; \mathrm{Sd}_{2}($ Moderate $)=\mathrm{Sd}_{\mathrm{y}} ; \mathrm{Sd}_{3}\left(\right.$ Extensive $=\mathrm{Sd}_{\mathrm{y}}+0.25\left(\mathrm{Sd}_{\mathrm{u}}-\mathrm{Sd}_{\mathrm{y}}\right)$, and $\mathrm{Sd}_{4}($ Complete $)=\mathrm{Sd}_{\mathrm{u}}$.

In addition, the HAZUS Project (FEMA - HAZUS99, 2016) proposes the same four damage states of the RISK-UE; however, it only associates them with the maximum interstory drift $\theta_{\text {max }}$ and proposes them according to the structural system and number of building floors. From the above, it is easy to assess the expected damage in a structure, either based on its spectral displacement, $\mathrm{Sd}$, or its maximum interstory drift, $\theta_{\max }$, which is presented for a particular seismic action. To do this, the calculation of the performance spectral displacement ( $\left.\mathrm{Sd}_{\mathrm{pP}}\right)$ is vital for an applied seismic demand. In addition, if the capacity curve is obtained based on the maximum interstory drift, $\theta_{\max }$, the Sdpp value can be obtained

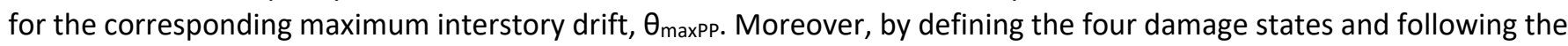
methodology proposed by RISK-UE project, it is possible to obtain the fragility curves and determine the damage probability for the Sdpp. We can, therefore, analyze the proposals of RISK-UE and HAZUS projects, and compare whether consideration of the limit service state and collapse prevention state proposed by the seismic regulations guarantees adequate behavior of a building throughout its useful life in the face of important seismic actions. 
The methodologies described above were used to study the expected seismic performance and damage of low-rise (3 story), medium-rise (7 story) and high-rise (13 story) steel buildings, based on Mexico's current seismic regulations (MDOC-CFE, 2015) and in accordance with the RISK-UE (Milutinovic and Trendafiloski, 2003) and HAZUS (FEMAHAZUS99, 2016) criteria. The southeastern region of Mexico was selected as the study area, considering the moderate, high, and very high seismicity activity in this region.

\section{SEISMIC ACTIONS}

In this study, Mexico was considered as the study area. Owing to its geographical location, it is subject to important seismic activity. Recent evidence of this have beeen found. In 2017, two important seismic events occurred in Mexico: one in the south on September 7, 2017, of Mw 8.2, and the other in the downtown area on September 19, 2017, of Mw 7.1. These events caused the loss of human life and significant damage to building structures, bridges, and temples (ERN, 2017). In these natural phenomena, the acceleration of the ground that occurred during the earthquake was the main danger to which the buildings were exposed. Seismic regulations define the hazardous seismic levels of each site based on the expected ground acceleration maxima and spectral accelerations for different structural periods, which is known as the design spectrum (Crisafulli and Villafañe, 2002). In addition to determining the correct seismic action with which a building should be designed, it is necessary to consider the type of foundation soil and structural properties of the building. For example, Mexico's regulations (MDOC-CFE, 2015 and NTCDS-RCDF, 2017) consider ductility (Q), response modification (Ro), redundancy $(\rho)$, and irregularity factors $(\alpha)$ to define the influence of building characteristics on the design spectrum. This study used the design spectra to define the seismic actions of each study site.

To have a panorama of moderate, high, and very high seismic actions, four cities in the southeast region of Mexico were used in this research as study areas: I) Centro, Tabasco; II) Tuxtla Gutierrez, Chiapas; III) Tapachula, Chiapas, and IV) Oaxaca, Oaxaca. In addition, two types of soil foundations (soft and rock) were considered for each city. Table 1 shows the seismic zoning and dynamic properties of the soil (wave propagation velocity, $V_{s}$, and volumetric weight, $\gamma_{s}$ ) considered for each city. The soils labelled "soft soil" and "rock soil" are equivalent to soil type E and type B, respectively, of the Soil Classification of the National Earthquake Hazard Reduction Program (NEHRP,1994).

Table 1. Seismic zoning and soil properties of the study site.

\begin{tabular}{|c|c|c|c|c|c|c|c|}
\hline \multirow[b]{2}{*}{ City } & \multirow{2}{*}{$\begin{array}{c}\text { Seismic Zone } \\
\text { (MDOC-CFE, 2015) }\end{array}$} & \multirow{2}{*}{$\begin{array}{l}\text { Maximum } \\
\text { acceleration in rock, } \\
\left(\mathrm{cm} / \mathrm{s}^{2}\right)\end{array}$} & \multirow{2}{*}{$\begin{array}{l}\text { Seismic } \\
\text { intensity }\end{array}$} & \multicolumn{2}{|c|}{$\mathrm{V}_{\mathrm{s}}(\mathrm{m} / \mathrm{s})$} & \multicolumn{2}{|c|}{$V_{s}\left(k N / m^{3}\right)$} \\
\hline & & & & $\begin{array}{l}\text { Soft soil } \\
\text { (SS) }\end{array}$ & $\begin{array}{l}\text { Rock soil } \\
\text { (RS) }\end{array}$ & $\begin{array}{l}\text { Soft soil } \\
\text { (SS) }\end{array}$ & $\begin{array}{l}\text { Rock soil } \\
\text { (RS) }\end{array}$ \\
\hline $\begin{array}{c}\text { Oaxaca, } \\
\text { Oaxaca (OA) }\end{array}$ & $\mathrm{D}$ & 220.59 & very high & 90 & 750 & 13 & 20 \\
\hline $\begin{array}{c}\text { Tapachula, Chiapas. } \\
\text { (TA) }\end{array}$ & D & 299.43 & very high & & & & \\
\hline $\begin{array}{l}\text { Tuxtla Gutierrez, } \\
\text { Chiapas. (TG) }\end{array}$ & C & 157.78 & high & & & & \\
\hline Centro, Tabasco. (EC) & B & 96.78 & moderate & & & & \\
\hline
\end{tabular}

Design spectra were obtained through the PRODISISv4.1 (2015) program for each site and foundation soil type. Furthermore, their respective modified design spectra (MDS) were obtained according to the MDOC-CFE (2015) seismic regulations using the following parameters: $Q=3, R_{0}=2, \alpha=1$, and $\rho=1.25$. These values correspond to steel structures for office buildings (Type B in accordance with MDOC-CFE, 2015), considered with regularity in plant and elevation, and its structural system consists of a series of orthogonal rigid frames. Figure 1 shows the modified design spectra (MDS) of each city and for each type of soil examined. Owing to its simplicity, the modified design spectra has found practical application in structural engineering in the estimation of seismic actions in buildings. The design spectra represent the seismic hazard intensities of a study site for buildings based on their structural periods and damping. In this study, the ductility $(Q)$, response modification $\left(R_{\circ}\right)$, redundancy $(\rho)$, and irregularity factors $(\alpha)$ were considered to be characteristics of the structural response of buildings to seismic actions. 


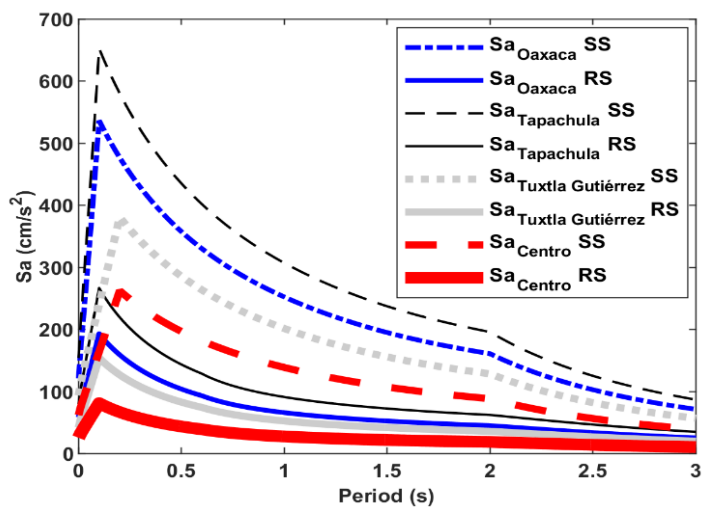

Figure 1. Modified design spectra according to MDOC-CFE (2015) for the four cities and two soil foundations.

\section{BUILDING DESCRIPTIONS}

Low-height ( 3 stories), medium-height ( 7 stories), and tall (13 stories) steel buildings were studied. All the buildings had a square plant (Figure 2(a)) with four bays (two bays at the ends of $8 \mathrm{~m}$ and two bays in the middle of $6 \mathrm{~m}$ ). For each one-third of the length, the bays had secondary beams, as shown in Figure 2(a). The buildings had a structural system consisting of a special rigid moment frame (SMF) with W sections, and a nominal yielding stress $f y=344.74 \mathrm{Mpa}$. In the principal frames, the connections were considered fully rigid (FR) according to the provisions for Prequalified Connections ANSI/AISC 358-16 (2016); moreover, the base support of each building was considered fixed. The focus of this study was the design and analysis of the central frame in the longitudinal direction (X-direction in Figure 2(a)). Figures 2(b), 2(c), and 2(d) show a two-dimensional (2-D) scheme of the central frame of each building (SMF3, SMF7, and SMF13).

The seismic design was performed using the SAP2000 v20 program (CSI Structures, 2018) according to ANSI/AISC $360-16$ (2016). A dead load (DL) of $6.5 \mathrm{kN} / \mathrm{m}^{2}$ and $5.5 \mathrm{kN} / \mathrm{m}^{2}$ were consideredfor the interstory andat the roof, respectively. The live loads (LL) were defined in accordance with NTCDS-RCDF (2017) and corresponded to office buildings; the interstory and roof LLs were $2.5 \mathrm{kN} / \mathrm{m}^{2}$ and $1 \mathrm{kN} / \mathrm{m}^{2}$, respectively. The seismic actions were defined by the modified design spectra of each of the four cities under study and for the two types of soil foundations. Thus, 24 buildings were designed for this study. Tables 2, 3, and 4 show the list of $W$ profiles used as beams and columns in each of the central frames analyzed.

Table 2. W sections in the central frame of the 3-story buildings (SMF 3) according to the ANSI/AISC 360-16 (2016).

\begin{tabular}{|c|c|c|c|}
\hline \multirow{2}{*}{ Building } & \multicolumn{2}{|c|}{ Columns } & \multirow{2}{*}{$\begin{array}{c}\text { Beams } \\
\text { W5 }\end{array}$} \\
\hline & W1 & W2 & \\
\hline OA-SS & W18X130 & W24X229 & W16X100 \\
\hline OA-RS & W14x74 & W18x119 & W12x72 \\
\hline TA-SS & W18X130 & W24X279 & W12x72 \\
\hline TA-RS & W14x99 & W18x119 & W12x58 \\
\hline TG-SS & W16x100 & W18x192 & W14x68 \\
\hline TG-RS & W16x67 & W18x97 & W14x48 \\
\hline CE-SS & W16x77 & W18x143 & W14x68 \\
\hline CE-RS & W16x57 & W18x76 & W14x48 \\
\hline
\end{tabular}

Table 3. W sections in the central frame of the 7-story buildings (SMF 7) according to theANSI/AISC 360-16 (2016).

\begin{tabular}{|c|c|c|c|c|c|}
\hline \multirow{2}{*}{ Building } & \multicolumn{3}{|c|}{ Columns } & \multicolumn{2}{|c|}{ Beams } \\
\hline & W1 & W2 & W3 & W5 & W6 \\
\hline OA-SS & W18x211 & W24×306 & W27x539 & W14x68 & W18x119 \\
\hline OA-RS & W16x100 & W18x192 & W21×201 & W12x53 & W14x61 \\
\hline TA-SS & W18x234 & W24x370 & W27x539 & W16x89 & W18x119 \\
\hline TA-RS & W16x100 & W18x192 & W21 201 & W12x53 & W14x61 \\
\hline TG-SS & W21×201 & W24×229 & W27x407 & W14x82 & W16x89 \\
\hline TG-RS & W16x89 & W18x119 & W21x147 & W14x61 & W16x57 \\
\hline CE-SS & W18x119 & W21x201 & W24x229 & W14x53 & W16x67 \\
\hline CE-RS & W16x77 & W18x106 & W21x122 & W14x53 & W16x50 \\
\hline
\end{tabular}


Table 4. W sections in the central frame of the 13-story buildings (SMF 13) according to the ANSI/AISC 360-16 (2016).

\begin{tabular}{|c|c|c|c|c|c|c|c|}
\hline \multirow{2}{*}{ Building } & \multicolumn{4}{|c|}{ Columns } & \multicolumn{3}{|c|}{ Beams } \\
\hline & W1 & W2 & W3 & W4 & W5 & W6 & W7 \\
\hline OA-SS & W21x122 & W24×176 & W30x261 & W33x318 & W12x87 & W14x82 & W16x89 \\
\hline OA-RS & W21x93 & W24x131 & W27x178 & W30x211 & W12x65 & W12x65 & W14x61 \\
\hline TA-SS & W21x147 & W27x217 & W30×326 & W33x387 & W12x87 & W16x100 & W18x119 \\
\hline TA-RS & W21x93 & W24x117 & W27x178 & W30x211 & W12x65 & W12x65 & W14x61 \\
\hline TG-SS & W18x106 & W21x166 & $W 24 \times 250$ & W27x307 & W14x61 & W16x67 & W18x65 \\
\hline TG-RS & W18x86 & W21x111 & W24×192 & W27x 217 & W14x61 & W16x57 & W18x50 \\
\hline CE-SS & W18x97 & W21x132 & W24x207 & W27x235 & W14x61 & W16x67 & W18x65 \\
\hline CE-RS & W18x76 & W21x111 & W24x176 & W27x194 & W14x61 & W16x57 & $W 18 \times 50$ \\
\hline
\end{tabular}
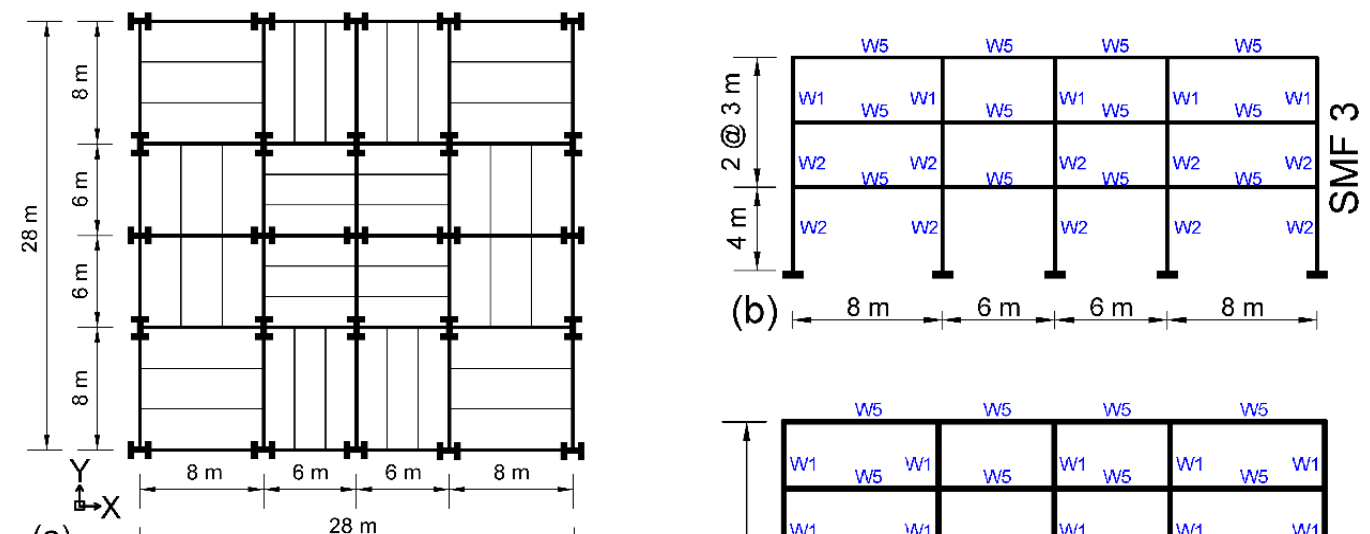

(b) $=8 \mathrm{~m}-1-6 \mathrm{~m}-6 \mathrm{~m}-1=8 \mathrm{~m}-1$

(a)

$28 \mathrm{~m}$
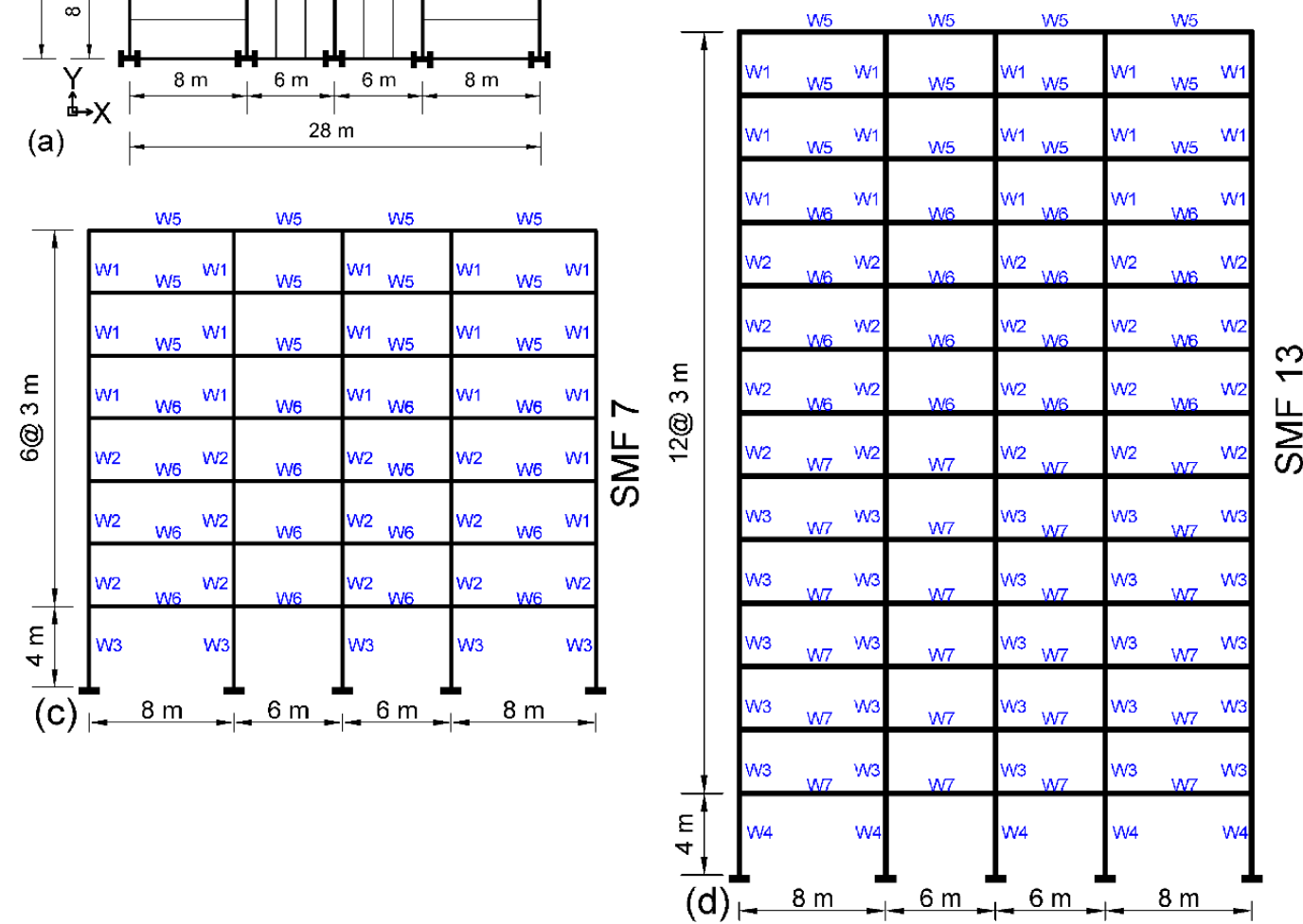

Figure 2. Geometric descriptions of the buildings and a 2-D view of the central frame of each building.

An NLSA of the central frame was performed using the Ruaumoko 2D program (Carr, 2002). The loads considered in these analyses were described as $1.0 \mathrm{CM}+0.2 \mathrm{CV}$ (PEER/ATC, 2010). The beams and columns were modeled with plastic hinges at each end. These plastic hinges follow the bilinear hysteresis rule with hardening and resistance reduction based on the ductility factor (Carr, 2002). The force values and ductility were calculated according to the modified IbarraMedina-Krawinkler model (IMK) (Ibarra et al., 2005; Lignos and Krawinkler, 2011, 2013). For more information on the definition of plastic hinges, it is recommended to review the study conducted by Diaz et al. (2017, 2018a) and Pinzon et al. (2020). Table 5 shows the main results obtained from the modal analysis of the central frame of each building associated with the fundamental period $T_{1}$, modal mass coefficient $\alpha_{1}$, and modal participation factor $P F_{1}$ for $T_{1}$. 
Table 5. Results of the modal analysis for the central frame of each building.

\begin{tabular}{|c|c|c|c|c|c|c|c|c|c|c|c|}
\hline \multicolumn{4}{|c|}{ 3-story building (SMF 3) } & \multicolumn{4}{|c|}{ 7-story building (SMF 7) } & \multicolumn{4}{|c|}{ 13-story building (SMF 13) } \\
\hline Buildings & $\begin{array}{l}\text { Fundamental } \\
\text { period } \mathrm{T}_{1}(\mathrm{~s} .)\end{array}$ & $\alpha_{1}$ & $\mathrm{PF}_{1}$ & Buildings & $\begin{array}{l}\text { Fundamental } \\
\text { period } \mathrm{T}_{1}(\mathrm{~s} .)\end{array}$ & $\alpha_{1}$ & $\mathrm{PF}_{1}$ & Buildings & $\begin{array}{l}\text { Fundamental } \\
\text { period } T_{1}(\mathrm{~s} .)\end{array}$ & $\alpha_{1}$ & $\mathrm{PF}_{1}$ \\
\hline OA-SS & 0.33 & 0.86 & 1.29 & OA-SS & 0.67 & 0.70 & 1.46 & OA-SS & 1.59 & 0.73 & 1.39 \\
\hline OA-RS & 0.55 & 0.87 & 1.31 & OA-RS & 1.15 & 0.77 & 1.37 & OA-RS & 2.09 & 0.77 & 1.33 \\
\hline TA-SS & 0.42 & 0.78 & 1.28 & TA-SS & 0.79 & 0.73 & 1.39 & TA-SS & 1.25 & 0.73 & 1.45 \\
\hline TA-RS & 0.60 & 0.84 & 1.31 & TA-RS & 1.16 & 0.77 & 1.37 & TA-RS & 2.11 & 0.76 & 1.33 \\
\hline TG-SS & 0.45 & 0.85 & 1.32 & TG-SS & 0.79 & 0.75 & 1.37 & TG-SS & 1.66 & 0.76 & 1.36 \\
\hline TG-RS & 0.59 & 0.87 & 1.29 & TG-RS & 1.15 & 0.80 & 1.32 & TG-RS & 1.92 & 0.77 & 1.34 \\
\hline CE-SS & 0.50 & 0.87 & 1.30 & CE-SS & 0.98 & 0.77 & 1.38 & CE-SS & 1.71 & 0.77 & 1.36 \\
\hline CE-RS & 0.65 & 0.89 & 1.28 & CE-RS & 1.23 & 0.80 & 1.33 & CE-RS & 1.94 & 0.78 & 1.34 \\
\hline
\end{tabular}

\section{SEISMIC PERFORMANCE ASSESSMENT}

This section presents the seismic performance assessment of buildings based on the NLSA and ATC-40 capacity spectrum method (1996). The capacity curves of the central frame of each building were obtained through adaptive pushover analysis (Satyarno, 2000) implemented in the Ruaumoko 2D program (Carr, 2002). In this process, the maximum interstory drift was obtained as $\theta_{\max }$. The capacity curves were converted into capacity spectra. For this, the values of the modal analysis of the buildings ( $\alpha_{1}, P F_{1}$ in Table 5) were substituted into equations for the ATC-40 (1996). The following formula proposed by Diaz et al. (2017) was used to determine the corresponding yield displacement:

$S d_{y}=\left(2 A_{s c}-\left(S a_{u}{ }^{\prime} S d_{u}\right)\right) /\left(\left(K_{i}^{\prime} S d_{y}\right)-S a_{u}\right)$

where $\mathrm{Sd}_{u}$ and $\mathrm{Sa}_{u}$ are the ultimate capacity points of the capacity spectrum, $\mathrm{A}_{\mathrm{sc}}$ is the area under the capacity spectrum, and $\mathrm{K}_{i}$ is the initial slope of the linear area of the capacity spectrum. Based on the yield spectral displacement $\mathrm{Sd}_{\mathrm{y}}$ and ultimate spectral displacement, $\mathrm{Sd}_{\mathrm{u}}$, the four damage states proposed by the RISK-UE project (Milutinovic and Trendafiloski, 2003) were defined for each building. Figure 3 shows the capacity spectra for the central frame of each building and their respective yield points $\left(\mathrm{Sd}_{\mathrm{y}}, \mathrm{Sa}_{\mathrm{y}}\right)$ and ultimate capacity points $\left(\mathrm{Sd}_{\mathrm{u}}\right.$, Sa $\left.\mathrm{Sa}_{\mathrm{u}}\right)$. Figures 4 and 5 present the respective ratios of spectral displacement $(\mathrm{Sd})$ and maximum interstory drift $\left(\theta_{\max }\right)$ for soft soil and rock soil.

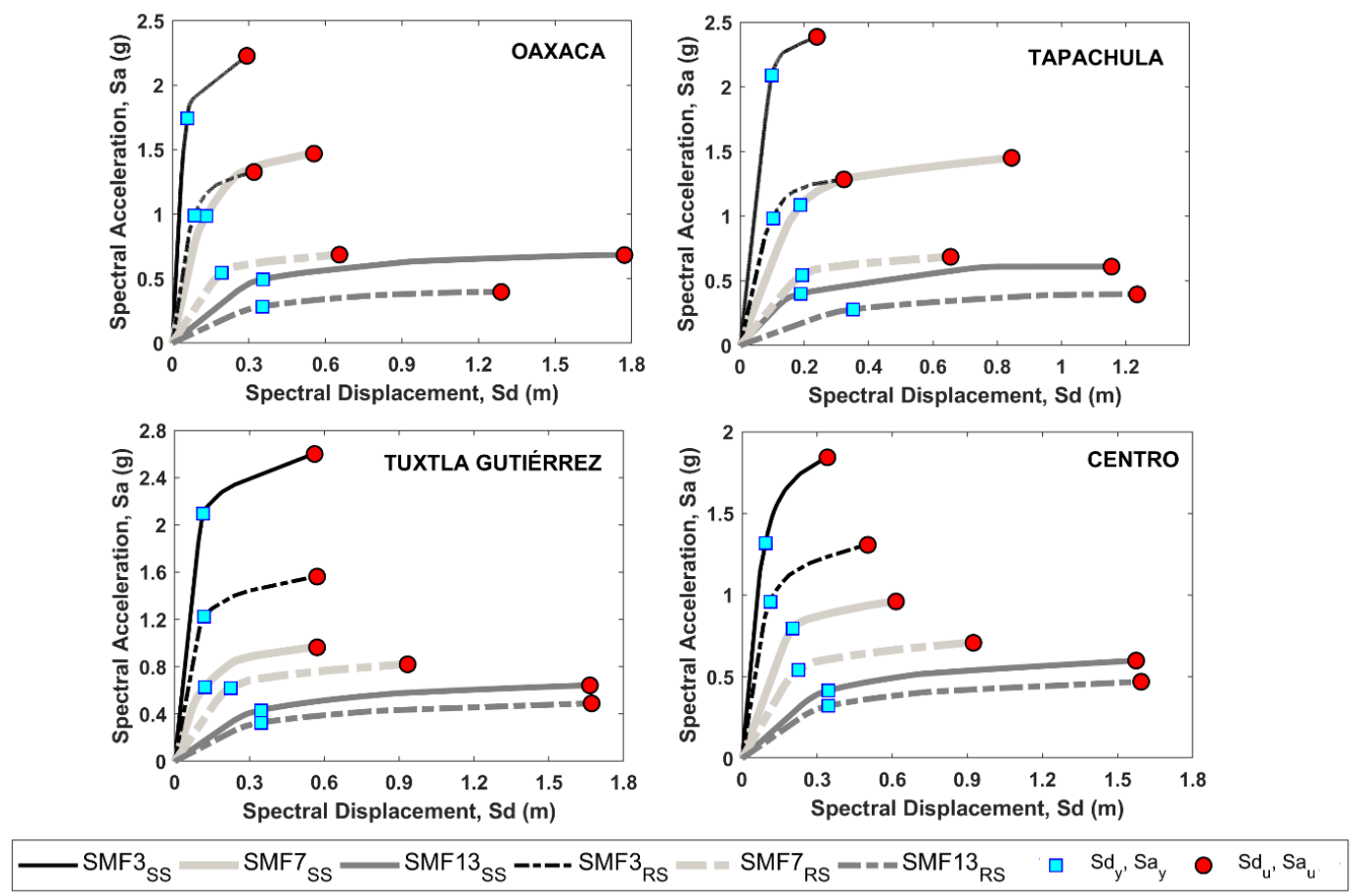

Figure 3. Capacity spectra for the central frame of each building. 

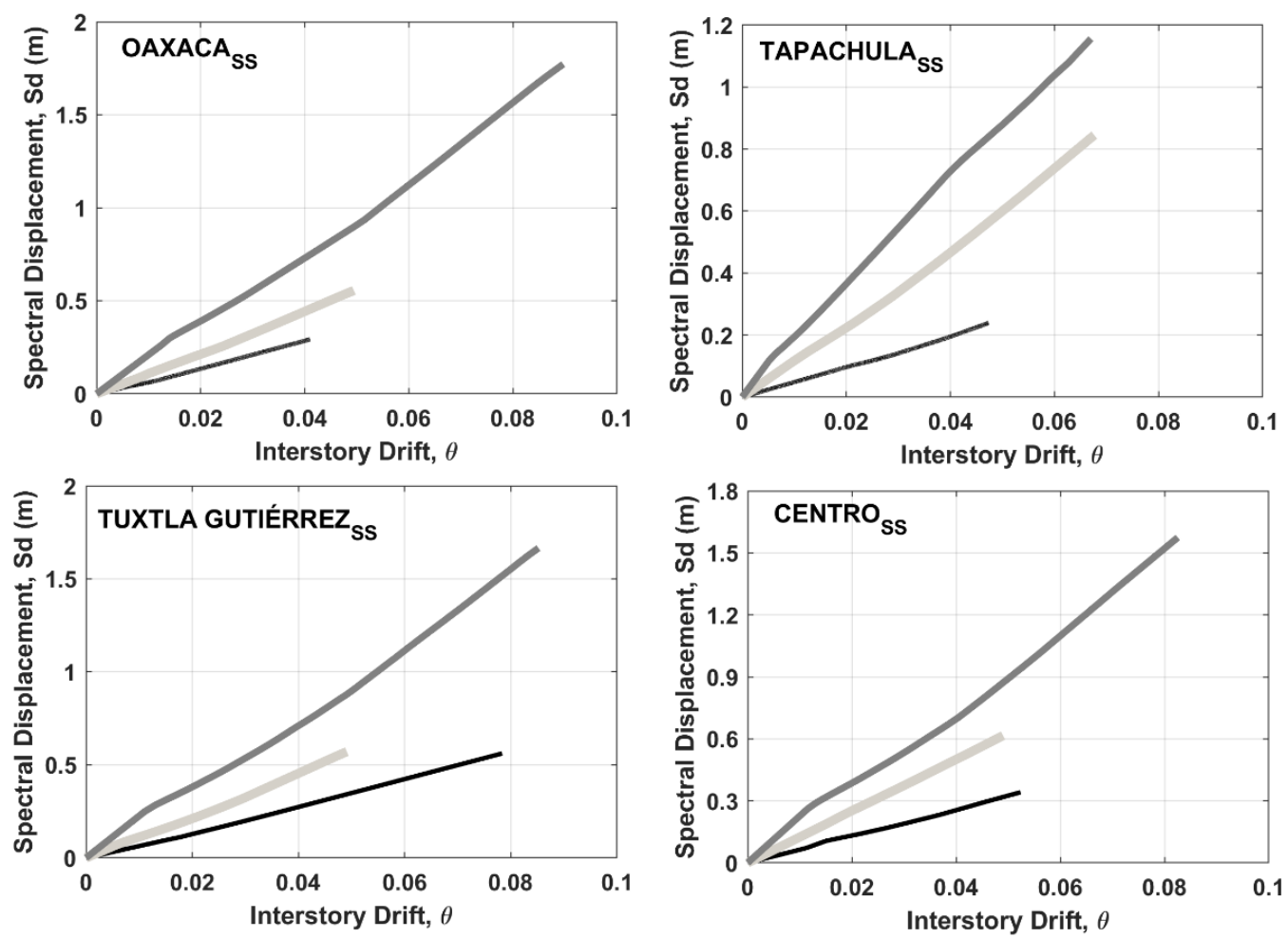

SMF3 SMF7 SMF13

Figure 4. Ratio $S d-\theta_{\max }$ for the central frame of each building in soft ground.
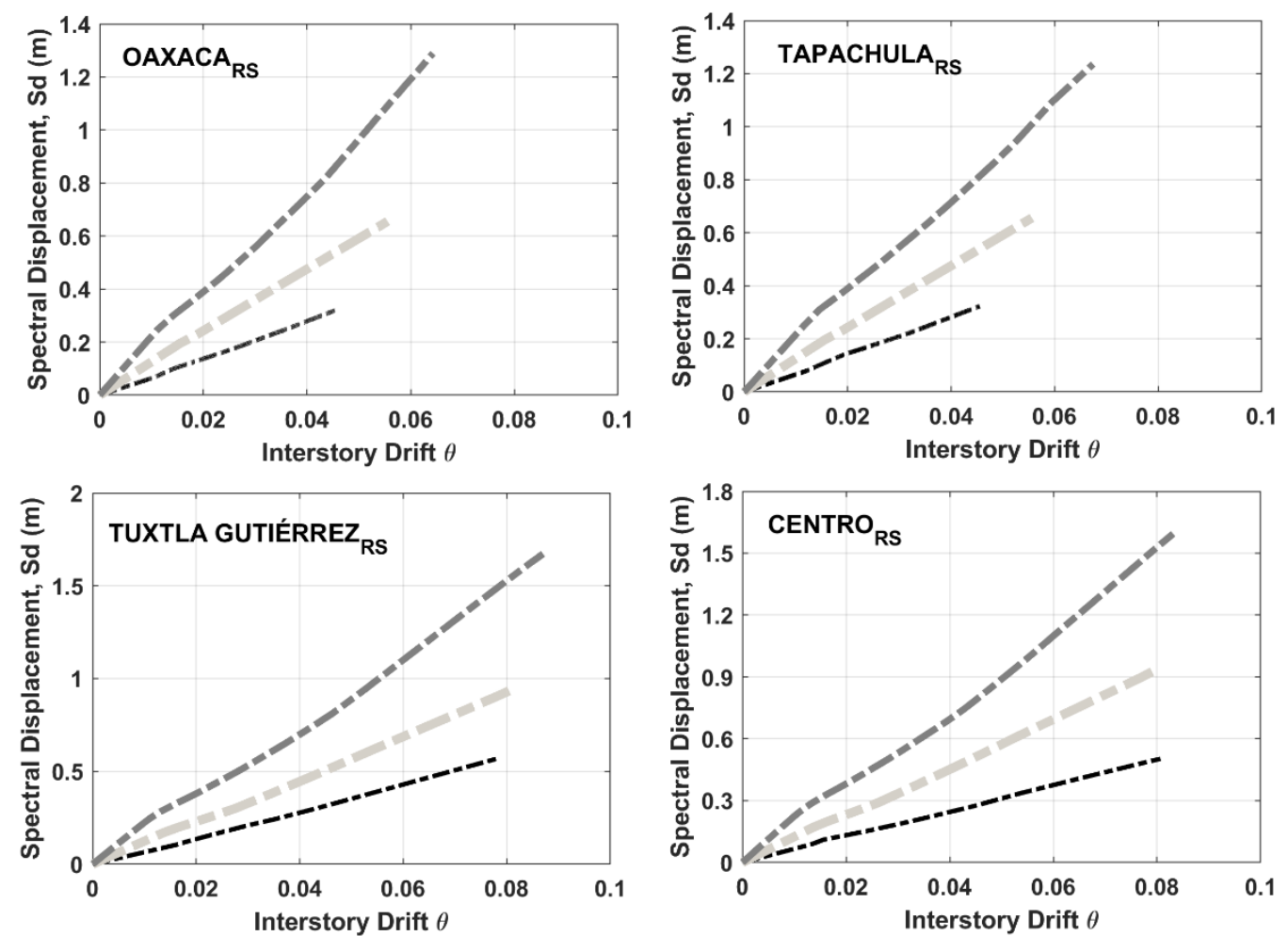

---- SMF3 - = SMF7 - =-SMF13

Figure 5. Ratio $S d-\theta_{\max }$ for the central frame of each building in rock ground. 
By process A of the capacity spectrum method of the ATC-40 (1996), each capacity spectrum is crossed with its respective modified design spectrum of each study area (MDS used in the structural design). Therefore, the spectral displacement of performance $\left(S d_{p P}\right)$ was obtained for each building. This evaluation is considered for the service state. To review the collapse prevention state as proposed in the MDOC-CFE (2015), the Sdpp values obtained must be multiplied by the $Q, R_{0}$, and $\rho$ seismic factors. For both the service and collapse prevention states, the relationships in Figure 4 were used to obtain their respective maximum performance interstory drift ( $\left.\theta_{\text {maxPP }}\right)$. Table 6 presents the results obtained for each building in the respective study areas.

Table 6. Seismic performance of the central frame of the buildings for their respective study area.

\begin{tabular}{|c|c|c|c|c|}
\hline \multirow[t]{2}{*}{ Buildings } & \multicolumn{2}{|c|}{ Service state } & \multicolumn{2}{|c|}{ Collapse prevention state } \\
\hline & $S d_{p p}(m)$ & $\theta_{\operatorname{maxPP}}$ & $S d_{P P}(m)$ & $\theta_{\operatorname{maxPP}}$ \\
\hline \multicolumn{5}{|c|}{ 3-story building (SMF 3) } \\
\hline OA-SS & 0.013 & 0.002 & 0.10 & 0.016 \\
\hline OA-RS & 0.011 & 0.002 & 0.083 & 0.013 \\
\hline TA-SS & 0.024 & 0.005 & 0.182 & 0.037 \\
\hline TA-RS & 0.012 & 0.002 & 0.089 & 0.014 \\
\hline TG-SS & 0.018 & 0.003 & 0.139 & 0.022 \\
\hline TG-RS & 0.007 & 0.001 & 0.050 & 0.008 \\
\hline CE-SS & 0.008 & 0.001 & 0.062 & 0.010 \\
\hline CE-RS & 0.007 & 0.001 & 0.051 & 0.008 \\
\hline \multicolumn{5}{|c|}{ 7-story building (SMF 7) } \\
\hline OA-SS & 0.042 & 0.004 & 0.313 & 0.030 \\
\hline OA-RS & 0.030 & 0.002 & 0.230 & 0.018 \\
\hline TA-SS & 0.064 & 0.005 & 0.476 & 0.040 \\
\hline TA-RS & 0.029 & 0.002 & 0.215 & 0.017 \\
\hline TG-SS & 0.044 & 0.003 & 0.328 & 0.030 \\
\hline TG-RS & 0.017 & 0.001 & 0.125 & 0.010 \\
\hline CE-SS & 0.009 & 0.0007 & 0.067 & 0.005 \\
\hline CE-RS & 0.030 & 0.002 & 0.226 & 0.018 \\
\hline \multicolumn{5}{|c|}{ 13-story building (SMF 13) } \\
\hline OA-SS & 0.140 & 0.006 & 1.050 & 0.056 \\
\hline OA-RS & 0.072 & 0.003 & 0.540 & 0.028 \\
\hline TA-SS & 0.121 & 0.005 & 0.910 & 0.040 \\
\hline TA-RS & 0.067 & 0.003 & 0.500 & 0.027 \\
\hline TG-SS & 0.122 & 0.005 & 0.913 & 0.040 \\
\hline TG-RS & 0.035 & 0.002 & 0.262 & 0.011 \\
\hline CE-SS & 0.008 & 0.0003 & 0.058 & 0.002 \\
\hline CE-RS & 0.066 & 0.003 & 0.592 & 0.0215 \\
\hline
\end{tabular}

\section{DAMAGE ASSESSMENT}

Considering the $\theta_{\operatorname{maxpp}}$ obtained for both the service state and collapse prevention state, the expected damage to the buildings under study was evaluated. The following three criteria were established to evaluate the expected damage:

a. MDOC-CFE Mexico regulations (2015). This regulation indicates a limit value of $\theta_{\max }=0.004$ for the service state where all non-structural elements can support appreciable deformations. For the collapse prevention state, a limit value of $\theta_{\max }=0.025$ was proposed.

b. HAZUS Project (FEMA - HAZUS99, 2016). Uses the proposed limit values of qmax associated with the four damage states for the steel rigid moment frame buildings considered in this project, as shown in Table 7. 
Table 7. Values of the allowable maximum interstory drift $\theta_{\max }$ according to the HAZUS Project (FEMA - HAZUS99, 2016) criteria for damage states in the analyzed steel rigid moment frame buildings.

\begin{tabular}{ccccc}
\hline Buildings & Slight & Moderate & Extensive & Complete \\
\hline Low-rise (S1L) & 0.0060 & 0.0120 & 0.0300 & 0.0800 \\
Mid-rise (S1M) & 0.0040 & 0.0080 & 0.0200 & 0.0533 \\
High-rise (S1H) & 0.0030 & 0.0060 & 0.0150 & 0.0400 \\
\hline
\end{tabular}

1. The RISK-UE Project (Milutinovic and Trendafiloski 2003). The Sd's associated with the four states of damage [Sd ${ }_{1}$ (Slight), $\mathrm{Sd}_{2}$ (Moderate), $\mathrm{Sd}_{3}$ (Extensive), and $\mathrm{Sd}_{4}$ (Complete)] obtained in the previous section can be used to calculate their respective $\theta_{\max }$ values. Using the $S d-\theta_{\max }$ ratios illustrated in Figure 4 , we can obtain the interstory drift $\theta_{\max 1}$ (Slight), $\theta_{\max 2}$ (Moderate), $\theta_{\max 3}$ (Extensive), and $\theta_{\max 4}$ (Complete) of each building. Table 8 shows the damage status values based on Sd and its corresponding $\theta_{\max }$ for each building.

Table 8. Building damage states based on the RISK-UE project (Milutinovic and Trendafiloski, 2003).

\begin{tabular}{|c|c|c|c|c|c|c|c|c|}
\hline \multirow{3}{*}{ Buildings } & \multicolumn{8}{|c|}{ Damage states } \\
\hline & \multicolumn{2}{|c|}{ Slight } & \multicolumn{2}{|c|}{ Moderate } & \multicolumn{2}{|c|}{ Extensive } & \multicolumn{2}{|c|}{ Complete } \\
\hline & $\mathrm{Sd}_{1}(\mathrm{~m})$ & $\theta_{\max 1}$ & $\mathrm{Sd}_{2}(\mathrm{~m})$ & $\theta_{\max 2}$ & $\mathrm{Sd}_{3}(\mathrm{~m})$ & $\theta_{\max 3}$ & $\mathrm{Sd}_{4}(\mathrm{~m})$ & $\theta_{\max 4}$ \\
\hline \multicolumn{9}{|c|}{ 3-story building (SMF 3) } \\
\hline OA-SS & 0.041 & 0.006 & 0.060 & 0.010 & 0.118 & 0.018 & 0.299 & 0.041 \\
\hline OA-RS & 0.060 & 0.010 & 0.086 & 0.013 & 0.145 & 0.021 & 0.320 & 0.046 \\
\hline TA-SS & 0.069 & 0.014 & 0.098 & 0.020 & 0.013 & 0.029 & 0.239 & 0.047 \\
\hline TA-RS & 0.072 & 0.010 & 0.102 & 0.015 & 0.158 & 0.022 & 0.323 & 0.046 \\
\hline TG-SS & 0.078 & 0.012 & 0.113 & 0.018 & 0.225 & 0.034 & 0.561 & 0.078 \\
\hline TG-RS & 0.082 & 0.013 & 0.118 & 0.018 & 0.230 & 0.033 & 0.571 & 0.079 \\
\hline CE-SS & 0.066 & 0.010 & 0.094 & 0.014 & 0.156 & 0.024 & 0.341 & 0.052 \\
\hline CE-RS & 0.079 & 0.012 & 0.113 & 0.016 & 0.210 & 0.034 & 0.502 & 0.080 \\
\hline \multicolumn{9}{|c|}{ 7-story building (SMF 7) } \\
\hline OA-SS & 0.093 & 0.009 & 0.133 & 0.012 & 0.239 & 0.023 & 0.555 & 0.049 \\
\hline OA-RS & 0.136 & 0.011 & 0.194 & 0.015 & 0.309 & 0.026 & 0.655 & 0.056 \\
\hline TA-SS & 0.131 & 0.011 & 0.188 & 0.017 & 0.352 & 0.031 & 0.845 & 0.067 \\
\hline TA-RS & 0.137 & 0.010 & 0.196 & 0.015 & 0.311 & 0.026 & 0.656 & 0.055 \\
\hline TG-SS & 0.084 & 0.007 & 0.120 & 0.011 & 0.233 & 0.022 & 0.571 & 0.049 \\
\hline TG-RS & 0.158 & 0.013 & 0.225 & 0.020 & 0.402 & 0.036 & 0.934 & 0.080 \\
\hline CE-SS & 0.142 & 0.011 & 0.202 & 0.016 & 0.306 & 0.024 & 0.615 & 0.049 \\
\hline CE-RS & 0.157 & 0.013 & 0.225 & 0.019 & 0.399 & 0.036 & 0.924 & 0.079 \\
\hline \multicolumn{9}{|c|}{ 13-story building (SMF 13) } \\
\hline OA-SS & 0.248 & 0.012 & 0.355 & 0.018 & 0.709 & 0.039 & 1.77 & 0.090 \\
\hline OA-RS & 0.247 & 0.011 & 0.353 & 0.018 & 0.587 & 0.032 & 1.289 & 0.064 \\
\hline TA-SS & 0.132 & 0.006 & 0.189 & 0.010 & 0.431 & 0.024 & 1.156 & 0.067 \\
\hline TA-RS & 0.247 & 0.011 & 0.352 & 0.018 & 0.573 & 0.032 & 1.236 & 0.067 \\
\hline TG-SS & 0.242 & 0.011 & 0.346 & 0.018 & 0.676 & 0.038 & 1.665 & 0.085 \\
\hline TG-RS & 0.242 & 0.011 & 0.346 & 0.018 & 0.678 & 0.039 & 1.672 & 0.067 \\
\hline CE-SS & 0.241 & 0.010 & 0.345 & 0.017 & 0.652 & 0.038 & 1.574 & 0.083 \\
\hline CE-RS & 0.241 & 0.010 & 0.345 & 0.017 & 0.657 & 0.038 & 1.594 & 0.083 \\
\hline
\end{tabular}

Figures 6,7 and 8 show a general overview of the expected damage to various buildings based on the $\mathrm{Sd}-\theta_{\max }$ ratio and the three criteria previously proposed for $\theta_{\operatorname{maxp}}$. 

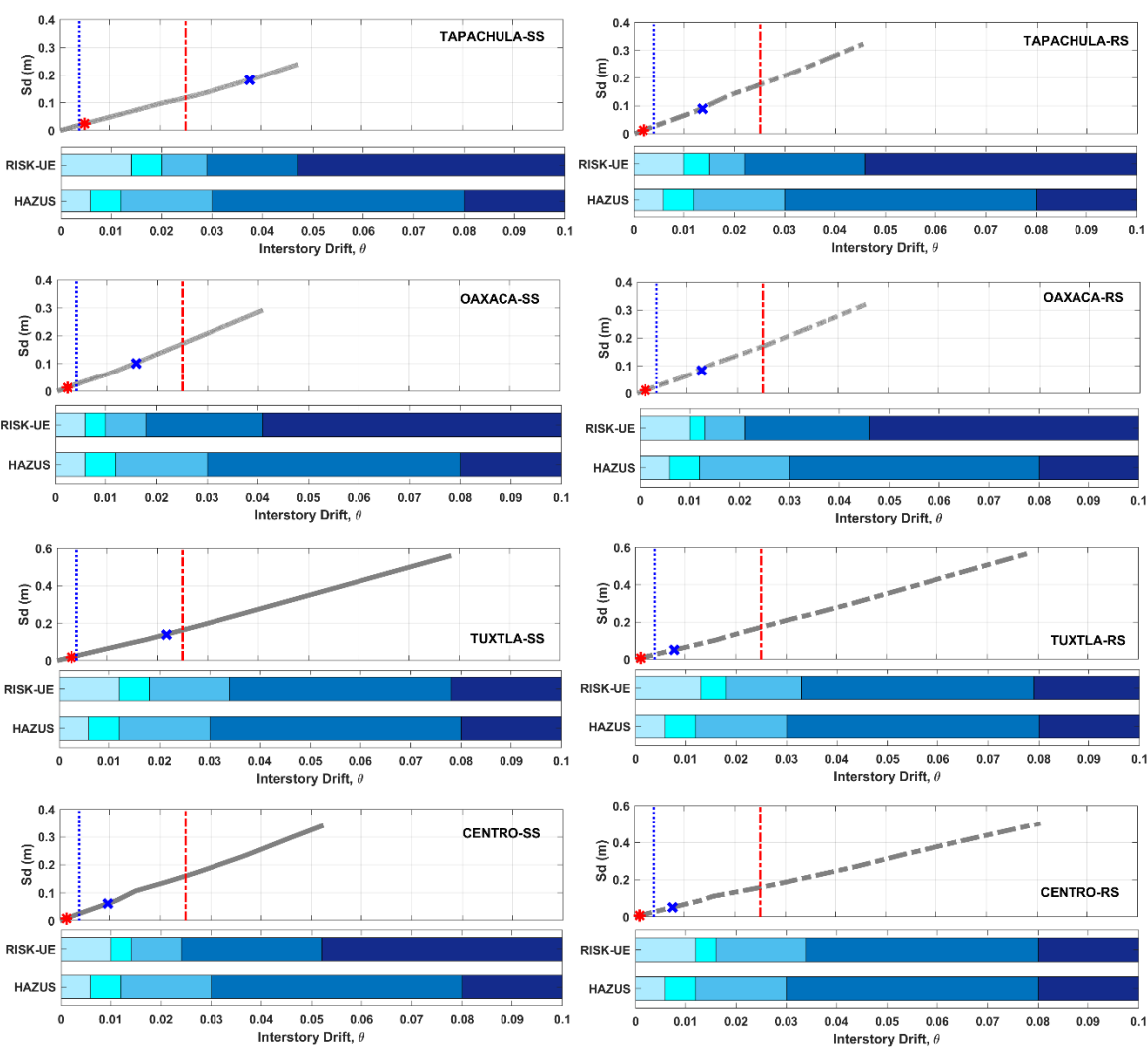

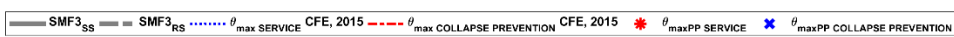

Damage States $\square$ Null $\square$ Slight $\square$ Moderate $\square$ Extensive $\square$ Complete

Figure 6. General overview of the expected damage for the 3-story buildings.
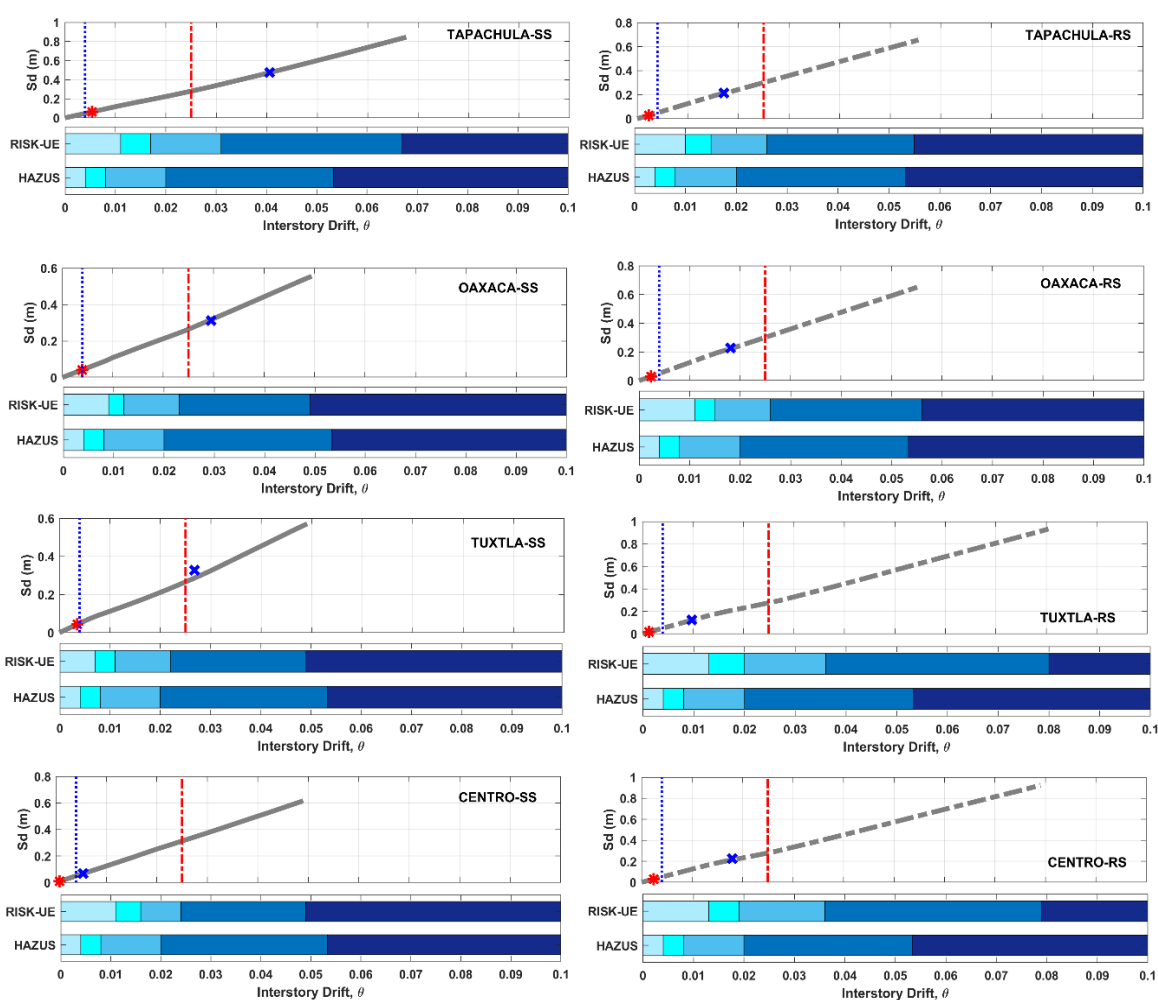

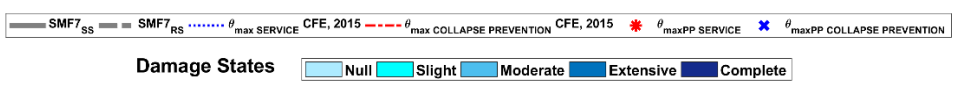

Figure 7. General overview of the expected damage for the 7-story buildings. 

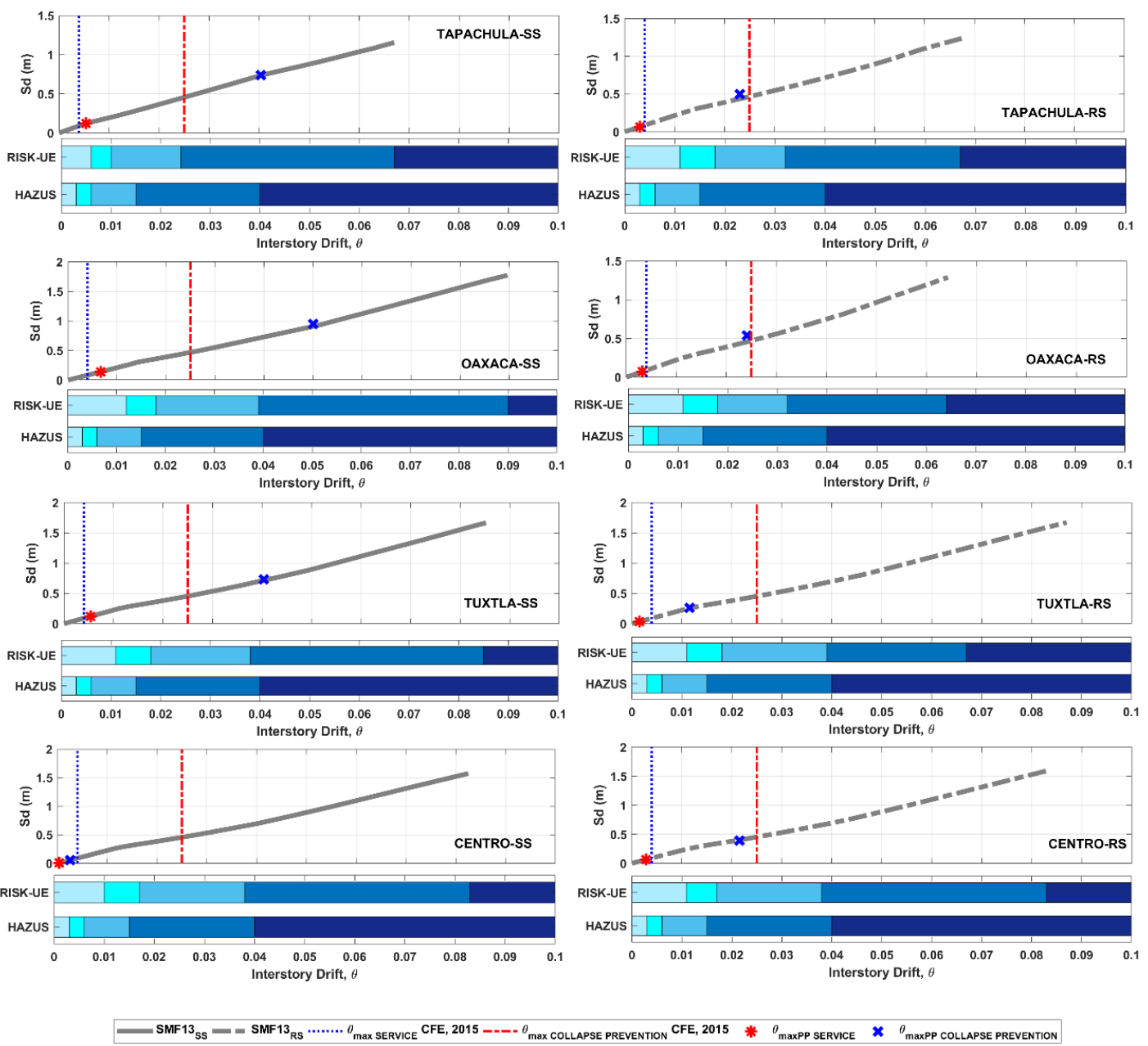

Damage States $\square$ Null $\square$ Slight $\square$ Moderate $\square$ Extensive $\square$ Complete

Figure 8. General overview of the expected damage for the 13-story buildings.

\section{RESULTS}

This section presents the results obtained from the seismic performance assessments of the buildings. Table 9 lists the expected damage for each building. Based on Table 9, an analysis of the results obtained for each type of seismic action is presented below.

\section{- Very high seismic actions (Oaxaca, Oaxaca)}

According to the provisions of the MDOC-CFE, we determined that the SMF13-SS building did not meet the criteria for the service and collapse prevention state. According to the HAZUS criterion for the service state, the SMF13-SS building would experience slight damage. For the collapse prevention state, according to the HAZUS and RISK-UE criteria, moderate to extensive damage would be experienced by the SS and RS buildings. In particular, based on the HAZUS complete damage of the SMF13-SS building would occur.

\section{- Very high seismic actions (Tapachula, Chiapas)}

According to the provisions of MDOC-CFE, the SMF3, SMF7, and SMF13 buildings located on SS soil type did not meet the service state and collapse prevention state criteria. Additionally, the SMF13-RS building did not meet the collapse prevention state. Considering the HAZUS criterion in the service state, the SMF7-SS and SMF13-SS buildings exhibited slight damage. In the collapse prevention state, based on both the HAZUS and RISK-UE criteria, the RS buildings and SS buildings exhibited moderate and extensive damage, respectively.

\section{- $\quad$ High seismic actions (Tuxtla Gutierrez, Chiapas)}

Using the CFE MDOC-CFE, the SMF7-SS building did not meet the collapse prevention state, and SMF13-SS did not meet the service state and collapse prevention state criteria. According to the HAZUS and RISK-UE criteria for the service 
state, the SMF13-SS building would have slight damage. The SMF3-SS building would have moderate damage in the collapse prevention state, while the SMF7-SS and SMF13-SS buildings would exhibit extensive damage. According to the HAZUS criterion with the collapse prevention state, the SMF3-RS building would have slight damage, and the SMF7-RS and SMF13-RS buildings would have moderate damage.

\section{- Moderate seismic actions (Centro, Tabasco)}

The buildings analyzed for the SS and RS soil conditions satisfactorily complied with the limits established in the MDOC-CFE regulations for the service state and collapse prevention state. According to the HAZUS and RISK-UE criteria for the service state, these buildings would have null damage. However, for the collapse prevention state, the SMF7-RS and SMF13-RS buildings would have moderate to extensive damage according to the HAZUS criterion and slight to moderate damage according to RISK-UE.

Table 9. Expected damage status in buildings according to the MDOC-CFE, HAZUS and RISK-UE criteria.

\begin{tabular}{|c|c|c|c|c|c|c|}
\hline \multirow{2}{*}{ Buildings } & \multirow{2}{*}{$\begin{array}{l}\text { Service state } \\
\text { MDOC-CFE } \\
2015(0.004)\end{array}$} & \multirow{2}{*}{$\begin{array}{c}\text { Collapse } \\
\text { prevention state } \\
\text { MDOC-CFE } 2015 \\
(\mathbf{0 . 0 2 5 )}\end{array}$} & \multicolumn{2}{|c|}{ Damage status (HAZUS) } & \multicolumn{2}{|c|}{$\begin{array}{l}\text { Damage Status } \\
\text { (RISK-UE) }\end{array}$} \\
\hline & & & $\theta_{\text {maxPP Service }}$ & $\begin{array}{c}\boldsymbol{\theta}_{\text {maxpp Collapse }} \\
\text { prevention }\end{array}$ & $\begin{array}{c}\theta_{\text {maxpp }} \\
\text { Service }\end{array}$ & $\begin{array}{c}\boldsymbol{\theta}_{\text {maxPP Collapse }} \\
\text { Prevention }\end{array}$ \\
\hline \multicolumn{7}{|c|}{ 3-story building (SMF 3) } \\
\hline OA-SS & $\checkmark$ & $\checkmark$ & Null & Moderate & Null & Moderate \\
\hline OA-RS & $\checkmark$ & $\checkmark$ & Null & Moderate & Null & Moderate \\
\hline TA-SS & $x$ & $x$ & Null & Extensive & Null & Extensive \\
\hline TA-RS & $\checkmark$ & $\checkmark$ & Null & Moderate & Null & Moderate \\
\hline TG-SS & $\checkmark$ & $\checkmark$ & Null & Moderate & Null & Moderate \\
\hline TG-RS & $\checkmark$ & $\checkmark$ & Null & Slight & Null & Null \\
\hline CE-SS & $\checkmark$ & $\checkmark$ & Null & Slight & Null & Null \\
\hline CE-RS & $\checkmark$ & $\checkmark$ & Null & Slight & Null & Null \\
\hline \multicolumn{7}{|c|}{ 7-story building (SMF 7) } \\
\hline OA-SS & $\checkmark$ & $\checkmark$ & Null & Extensive & Null & Extensive \\
\hline OA-RS & $\checkmark$ & $\checkmark$ & Null & Moderate & Null & Moderate \\
\hline TA-SS & $x$ & $x$ & Slight & Extensive & Null & Extensive \\
\hline TA-RS & $\checkmark$ & $\checkmark$ & Null & Moderate & Null & Moderate \\
\hline TG-SS & $\checkmark$ & $x$ & Null & Extensive & Null & Extensive \\
\hline TG-RS & $\checkmark$ & $\checkmark$ & Null & Moderate & Null & Null \\
\hline CE-SS & $\checkmark$ & $\checkmark$ & Null & Slight & Null & Null \\
\hline CE-RS & $\checkmark$ & $\checkmark$ & Null & Moderate & Null & Slight \\
\hline \multicolumn{7}{|c|}{ 13-story building (SMF 13) } \\
\hline OA-SS & $x$ & $x$ & Slight & Complete & Null & Extensive \\
\hline OA-RS & $\checkmark$ & $\checkmark$ & Null & Extensive & Null & Moderate \\
\hline TA-SS & $x$ & $x$ & Slight & Extensive & Null & Extensive \\
\hline TA-RS & $\checkmark$ & $x$ & Null & Extensive & Null & Moderate \\
\hline TG-SS & $x$ & $x$ & Slight & Extensive & Null & Extensive \\
\hline TG-RS & $\checkmark$ & $\checkmark$ & Null & Moderate & Null & Null \\
\hline CE-SS & $\checkmark$ & $\checkmark$ & Null & Null & Null & Null \\
\hline CE-RS & $\checkmark$ & $\checkmark$ & Null & Extensive & Null & Moderate \\
\hline
\end{tabular}

$\checkmark$ Meets the criterion; $\mathbf{x}$ does not meet the criterion.

\section{DISCUSSION}

Analyzing the three criteria, we can establish that, in their service state, all the buildings analyzed in this study will exhibit adequate behavior and null damage. Only some cases where the $\theta_{\text {maxpp }}$ exceeds the limit allowed in the MDOCCFE (2015) or where the damage estimated by HAZUS (FEMA - HAZUS99, 2016) is slight are considered conservative, and it is observed that $\theta_{\operatorname{maxpP}}$ does not exceed the $\theta_{\max }$ associated with the yielding condition according to the capacity 
spectrum of each building. Thus, we can say that the interstory drift of $\theta_{\max }=0.004$ indicated in the MDOC-CFE and those proposed by the RISK-UE (Milutinovic and Trendafiloski, 2003) and HAZUS criteria are adequate for damage control in the service state, independent of the type of seismic action.

For the collapse prevention state, it was observed that, in some cases, the limit allowed in the MDOC-CFE was exceeded, and there was the possibility of damage occurring based on the HAZUS or RISK-UE criteria. In none of the cases was the ultimate capacity point exceeded, whereby the buildings will not collapse. However, it can be assumed that, for seismic actions of magnitudes equal to or larger than the design actions established by the seismic regulation, the value of the $\theta_{\max }$ corresponding to the yielding condition of the buildings could be exceeded. If this occurs, buildings will experience damage as follows: (i) in buildings in areas with very high seismic action (such as: Oaxaca, Oaxaca and Tapachula, Chiapas): moderate damage to those constructed on rock soil (RS) and extensive damage to those constructed on soft soil (SS) were observed; (ii) in buildings in areas with high seismic actions (example: Tuxtla Gutierrez, Chiapas), considering soft soil (SS) buildings: the results revealed slight damage to low-rise buildings, moderate damage to medium-rise buildings, and extensive damage to high-rise buildings; (iii) in building in areas with moderate seismic action (in this case Centro, Tabasco): considering rock soil (RS) buildings, slight damage to medium-rise buildings and moderate damage to high-rise buildings were observed.

It is important to recognize that setting the service state or collapse prevention state limits to control damage to buildings is not easy. As discussed in this investigation, some of the buildings that were designed according to the seismic Mexico's regulations (NTCDS-RCDF, 2017 and MDOC-CFE, 2015) did not comply with the limits established in MDOC-CFE for the calculated $\theta_{\text {maxPp }}$, especially high-rise buildings in areas with high or very high seismic action. In these situations, it is advisable to use some of the other existing criteria, such as the HAZUS or RISK-UE criteria, to determine the expected damage in a more appropriate manner. The values presented in this study can be used as a reference to evaluate damage to buildings.

In areas with very high seismic action, the buildings that meet all the seismic design requirements of current regulations will remain ductile, develop large deformations, and exhibit robustness to the collapse in the face of very intense seismic action. However, it should be noted that these buildings could experience moderate to extensive damage and might need to be repaired.

\subsection{Comparison of the ATC-40 method and dynamic analyses}

In this section, the validity of the results obtained using the ATC-40 method is discussed. This analysis method is no longer a state-of-the-art method. However, this does not detract from its validity and simplicity, especially for evaluations of buildings, such as the buildings analyzed here, whose structural responses are dominated by their first mode of vibration or fundamental period and that have an expected structural response in its linear zone. In the last decade, simple tools that can be used to carry out seismic evaluations in a practical way in the field of applied structural engineering have been developed (Vargas et al. 2013, 2019, Pujades et al. 2015, Georgios Baltzopoulos et al., 2017, Diaz et al. 2017, 2018a, b). Although these methods are not novel, their theoretical value in certain instances cannot be discounted.

The linear- and non-linear dynamic analyses have advantages but entails greater complexity if a well-established computational tool is not available. To compare the performances of the ATC-method and dynamic analyses, a case study is presented for the three TA SS buildings analyzed in this study. The analyses were performed using three accelerograms compatible with the demand spectrum previously employed in determining their Sdpp through the ATC-40 method. In the methodology proposed in this paper, the $S_{p P}$ (or their equivalent, roof displacement, $\delta_{p p}$ and $\theta_{\text {maxpP }}$ ) values obtained represent the service condition, and for the collapse prevention condition, these ( $\mathrm{Sd} d_{\mathrm{PP},} \delta_{\mathrm{PP}}$ or $\theta_{\operatorname{maxpP}}$ ) are multiplied by the $Q, R_{0}$, and $\rho$ seismic factors, based on the MDOC-CFE (2015). Since the results obtained in this research through the ATC-40 method (service condition) does not reach the nonlinear behavior of the buildings, the dynamic analyses were also performed using the accelerograms scaled by the seismic factors employed for the modified design spectrum (MDS) in order to compare the results from the collapse prevention condition. Thus, in this case, the structural response of the buildings is markedly nonlinear.

Figure 9 shows the ATC-40 method for TA SS buildings, where the crossing between the demand spectrum (MDS) of the TA SS used in their structural design and the respective capacity spectra of each building can be observed. The following performance spectral displacements for the service state $\left(\mathrm{S}_{\text {state }}\right)$ were obtained: $\mathrm{Sd}_{\mathrm{PP}} \mathrm{Sstate}$ for SMF3 $=0.024 \mathrm{~m}$, SdPP Sstate for SMF7 $=0.064 \mathrm{~m}$, and SdPP Sstate for SMF13 $=0.121 \mathrm{~m}$. Using the PF , from Table 5 of each building $\left(\mathrm{PF}_{1} \mathrm{SMF}\right.$ $=1.28, \mathrm{PF}_{1} \mathrm{SMF} 7=1.39$, and $\left.\mathrm{PF}_{1} \mathrm{SMF} 13=1.45\right)$, the respective roof displacements, $\delta$, were calculated to obtain $\delta_{\mathrm{PP}} \mathrm{Sstate}$ SMF3 $=0.0307 \mathrm{~m}, \delta_{\text {PP Sstate }}$ SMF7 $=0.0889 \mathrm{~m}$, and $\delta_{\text {PP Sstate }}$ SMF13 $=0.175 \mathrm{~m}$. Finally, multiplying by the $Q, R_{0}$, and $\rho$ seismic 
factors, the values for the collapse prevention state $\left(\mathrm{CP}_{\text {state }}\right)$ were: $\delta_{\mathrm{PP}}$ CPstate $\mathrm{SMF} 3=0.23 \mathrm{~m}, \delta_{\mathrm{PP}}$ CPstate $\mathrm{SMF7}=0.667 \mathrm{~m}$, and $\delta_{\mathrm{PP}}$ CPstate SMF13 $=1.313 \mathrm{~m}$, respectively.

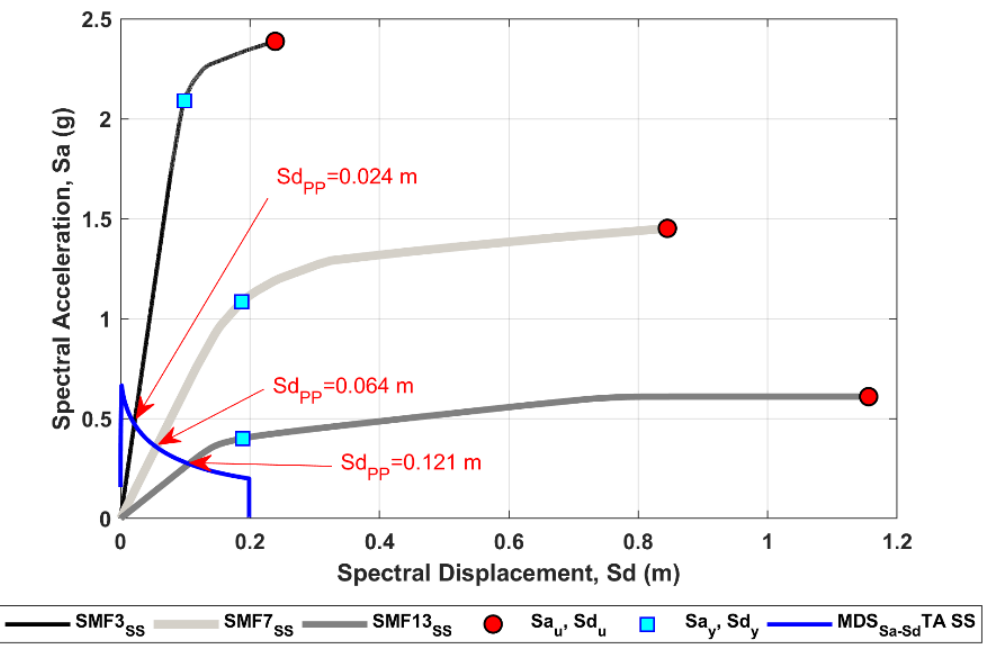

Figure 9. $\mathrm{Sd}_{\mathrm{pp}}$ values obtained with ATC-40 method for soft-soil buildings in Tapachula.

To compare these results with those obtained through the dynamic analyses, three synthetic accelerograms with different durations, $\mathrm{AcC}_{\text {Matched } 1}=80.93 \mathrm{~s}, \mathrm{Acc}_{\text {Matched } 3}=70.29 \mathrm{~s}$, and $\mathrm{AcC}_{\text {Matched } 3}=60.23 \mathrm{~s}$, were generated through PRODISIS software based on the MDOC-CFE (2015) recommendations. The response spectra of these synthetic accelerograms were matched with the MDS of the MDOC-CFE (2015) for soft soil in Tapachula. In this study, the spectral matching technique presented by Pinzon et al. (2021) was used. In Figure 10, the generated synthetic accelerograms and their respective spectra that matched with the target spectrum are shown. For the collapse prevention state, these seismic actions were multiplied by the seismic factors $(Q=3, R o=2$ and $\rho=1.25)$.
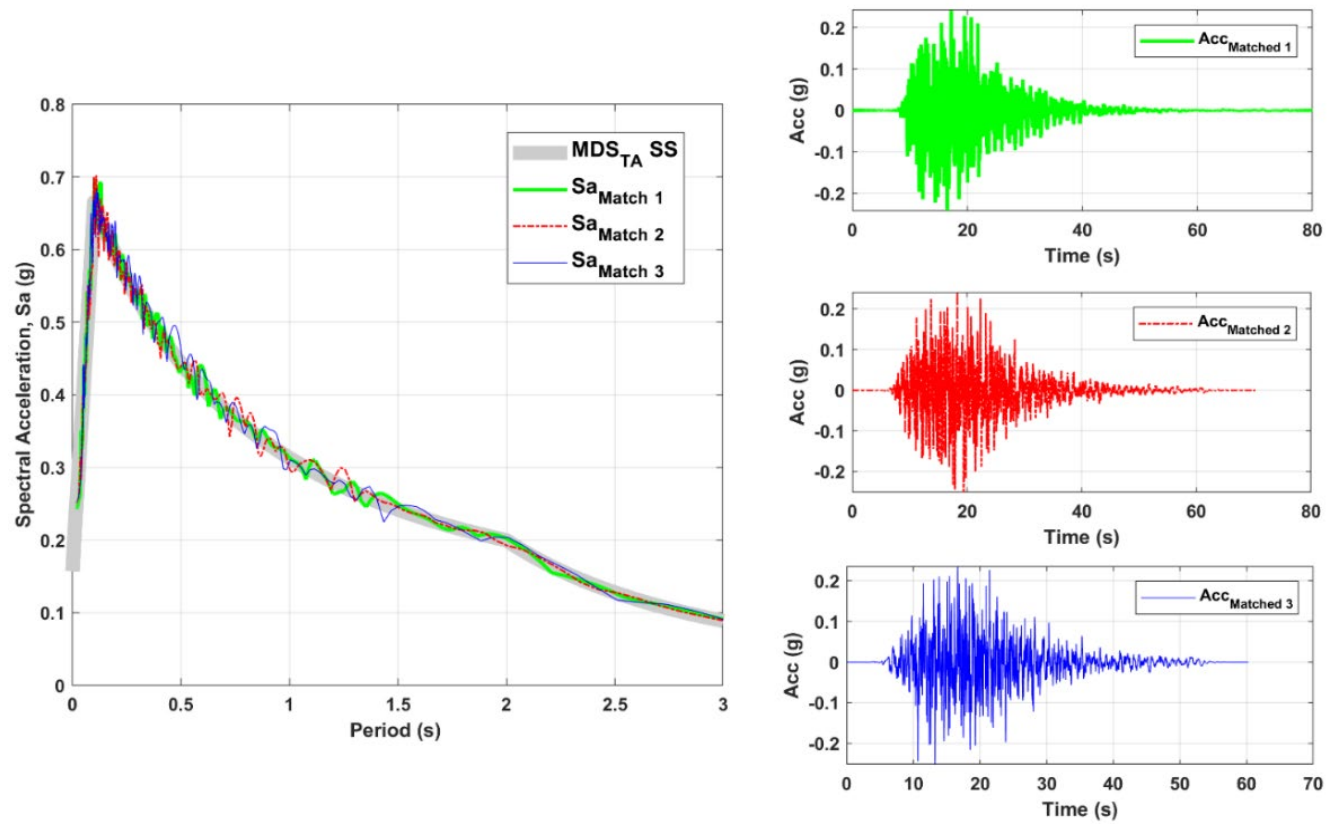

Figure 10. Modified design spectrum (MDS) MDOC-CFE (2015) for Tapachula soft-soil and the three matched spectra generated from the synthetic accelerograms.

The dynamic analyses were performed using the Ruaumoko 2D program (Carr, 2002). The results for the roof displacement, $\delta$, in the TA-SS buildings as a function of the response history analysis are shown in Figure 11 . The mean values of the maximum $\delta$ for each building were obtained as follows; for the service state: $\delta_{\text {mean(max) }} S M F 3=0.0305 \mathrm{~m}$, $\delta_{\text {mean }(\max )}$ SMF7 $=0.0847 \mathrm{~m}$, and $\delta_{\text {mean(max) }} S M F 13=0.170 \mathrm{~m}$, and for the collapse prevention state: $\delta_{\text {mean }(\max )} \mathrm{SMF} 3=0.216$ $\mathrm{m}, \delta_{\text {mean(max) }} \mathrm{SMF7}=0.611 \mathrm{~m}$ and $\delta_{\operatorname{mean}(\max )} \mathrm{SMF} 13=1.202 \mathrm{~m}$. Table 10 shows a comparison of the results of the dynamic 
analyses and the ATC-40 method for this case study. It was observed that the $\delta_{\max }$ of the dynamic analysis was similar and in the same range as the $\delta_{\text {pp }}$ of the ATC-40 method for the three buildings in the service state. For the $\delta_{\text {mean }}$ (max) of the collapse prevension state there are differences of $6.5 \%$ for the SMF3, $7.9 \%$ for the SMF7 and $9.2 \%$ for the SMF13.
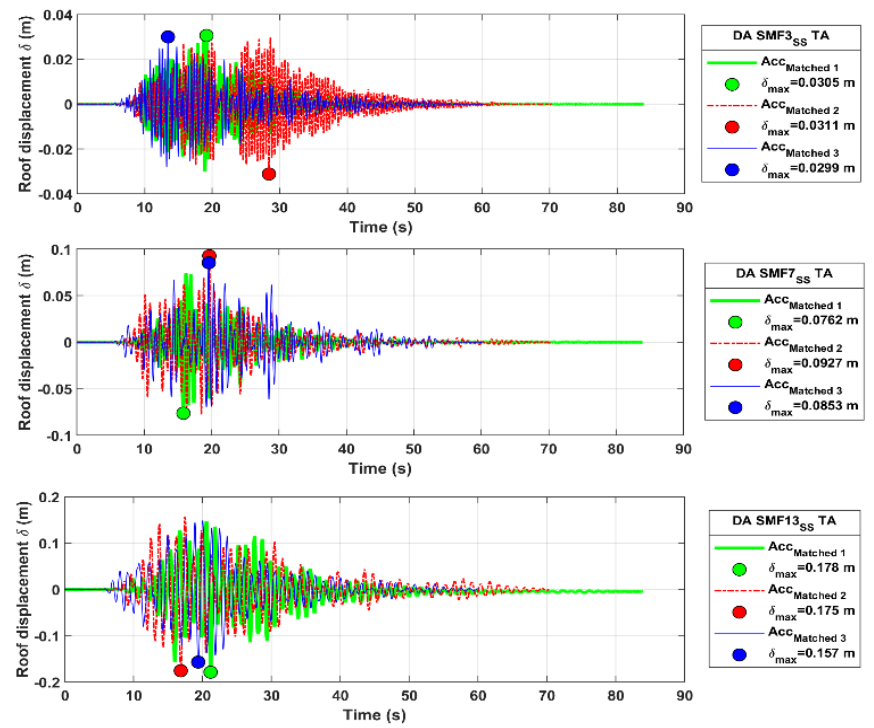

a)

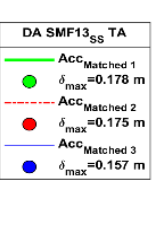

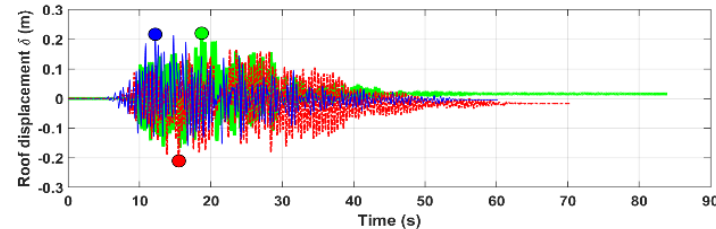
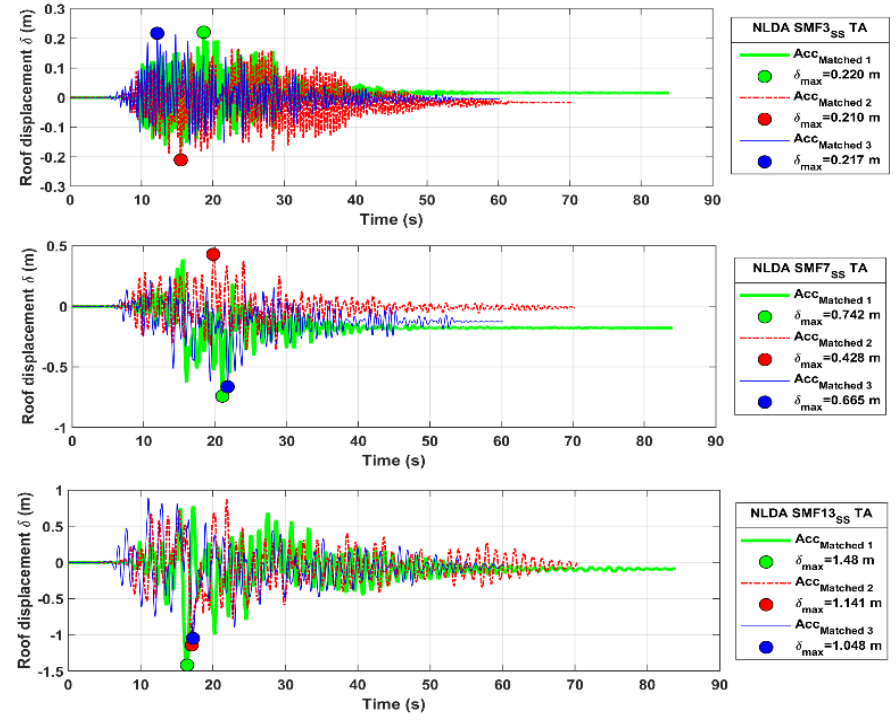

b)

Figure 11. Seismic response of the roof displacement of the TA-SS buildings for the a) service state and b) collapse prevention state obtained through dynamic analyses.

Table 10. Roof displacements, $\delta$, of the TA-SS buildings obtained by the ATC- 40 method and the dynamic analyses.

\begin{tabular}{|c|c|c|c|c|c|c|c|}
\hline \multirow{3}{*}{ Building } & \multicolumn{2}{|c|}{ ATC-40 } & \multirow{3}{*}{ Acc } & \multicolumn{2}{|c|}{ DA } & \multirow{2}{*}{\multicolumn{2}{|c|}{ NLDA }} \\
\hline & \multirow{2}{*}{$\begin{array}{c}\text { Service state } \\
\delta_{\mathrm{PP}}(\mathrm{m})\end{array}$} & \multirow{2}{*}{$\begin{array}{c}\text { Collapse } \\
\text { prevention state }\end{array}$} & & \multirow[b]{2}{*}{$\delta(\mathrm{m})$} & \multirow[b]{2}{*}{$\delta_{\text {mean(max) }}(\mathrm{m})$} & & \\
\hline & & & & & & $\delta(\mathrm{m})$ & $\delta_{\text {mean(max) }}(m)$ \\
\hline \multirow[t]{3}{*}{ SMF3 $_{\text {ss }}$ TA } & 0.0307 & 0.230 & Matched 1 & 0.0305 & 0.0305 & 0.220 & 0.216 \\
\hline & & & Matched 2 & 0.0311 & & 0.210 & \\
\hline & & & Matched 3 & 0.0299 & & 0.217 & \\
\hline \multirow[t]{3}{*}{ SMF7 $_{\text {sS }}$ TA } & 0.0889 & 0.667 & Matched 1 & 0.0762 & 0.0847 & 0.742 & 0.611 \\
\hline & & & Matched 2 & 0.0927 & & 0.428 & \\
\hline & & & Matched 3 & 0.0853 & & 0.665 & \\
\hline \multirow[t]{3}{*}{ SMF13ss TA } & 0.175 & 1.313 & Matched 1 & 0.178 & 0.170 & 1.418 & 1.202 \\
\hline & & & Matched 2 & 0.175 & & 1.141 & \\
\hline & & & Matched 3 & 0.157 & & 1.048 & \\
\hline
\end{tabular}

This case study shows the compatibility of results obtained with the ATC-40 method and the dynamic analyses for the studied buildings. Buildings whose structural response is dominated by their first mode of vibration or fundamental period (Diaz et. al. 2018b). It is observed that the differences between the $\delta_{\text {PP CPstate }}$ and the dynamic analysis are relatively low (under 10\%) and become greater as the number of stories increases. This fact could be attributed to the influence of higher modes in the response, which is not captured in the static analysis (Diaz et. al. 2018a). Despite these differences, the results obtained from the ATC method are more conservative, which demonstrates the efficiency of this methodology, especially for low and regular buildings.

\section{CONCLUSIONS}

This paper focuses on the seismic performance assessment of steel buildings of different heights exposed to different types of seismic actions. In this study, nonlinear static analysis (NLSA) and the capacity spectrum method (ATC- 
$40,1996)$ were used to determine the performance point. Three criteria were considered based on the maximum interstory drift, $\left(\theta_{\max }\right)$, i.e., the MDOC-CFE (2015), HAZUS (FEMA - HAZUS99, 2016), and RISK-UE (Milutinovic and Trendafiloski, 2003), to determine the expected damage to the buildings. The main conclusions are as follows: I) The service state established by MDOC-CFE (2015) is suitable for damage control for the service condition and also according to the limit of slight damage proposed by the RISK-UE project; II) in areas with high seismic demand, the collapse prevention state should be established with caution, because, if a highly permissible limit is selected, significant damage can occur during the useful life of buildings owing to seismic actions equal to or greater than those considered in seismic design; III) the HAZUS criterion is more conservative in evaluating damage than the RISK-UE criterion; however, it is more stringent for medium-rise and high-rise buildings; IV) the RISK-UE criterion may be more dependent on the expected damage to the structures than other criteria because it is based on the yielding point and ultimate capacity point obtained from the capacity spectrum of the buildings; and V) for future seismic design regulations of steel buildings in Mexico, we recommend establishing values that associate the $\theta_{\max }$ with damage states and with the levels of seismic demand. Thus, the building seismic design objectives may be set for each seismic zone. Although the results obtained reveal that the Mexican seismic design code achieves the objective of preventing the collapse of the buildings analyzed here, in high seismicity zones, it is necessary to establish other control limits for slight or moderate damage. Furthermore, control limits for those seismic actions of great magnitude not causing significant damage during the useful life of the buildings should also be established.

\section{Acknowledgements}

This research was funded by the UJAT-EXB-229 part of Project for the Teacher Improvement Program (PRODEP), Mexico. The first author thanks the scholarships of the Universidad Juárez Autónoma de Tabasco (UJAT) and PROMEP for studies of his bachelor's degree in Civil Engineering.

Author's Contribuitions: Conceptualization, D Arcos Díaz, SA Diaz, and H Jesus; Investigation, D Arcos Díaz, SA Diaz and RS Mora Ortiz; Methodology, D Arcos Díaz, SA Diaz and LA Pinzón; Software; SA Diaz and LA Pinzón; Validation, D Arcos Díaz, SA Diaz and H Jesus; Writing - original draft, SA Diaz, D Arcos Díaz and H Jesus; Writing - review \& editing, SA Diaz, and $\mathrm{H}$ Jesus and LA Pinzón; Visualization, H Jesus and RS Mora Ortiz; Funding acquisition, SA Diaz and RS Mora Ortiz.

Editor: Pablo Andrés Muñoz Rojas

\section{References}

American Society of Civil Engineers (ASCE) (2016). Minimum Design Loads for Buildings and Other Structures, ASCE/SEI 7-16, American Society of Civil Engineers/Structural Engineering Institute, Reston, Virginia. EUA. Available in: https://www.asce.org/structural-engineering/asce-7-and-sei-standards/

Andrade, I. L. E. (2004). Control de la deriva en las normas de diseño sismorresistente. Pontificia Universidad Católica Del Perú Facultad De Ciencias E Ingeniería, Peru. (Civil Engineering Thesis in Spanish). Available in:

http://hdl.handle.net/20.500.12404/160

ANSI/AISC 358-16 (2016). Prequalified connections for special and intermediate steel moment frames for seismic applications, American National Standard and American Institute of Steel Construction. EUA. Available in:

https://www.aisc.org/products/publication/standards/prequalified-connections-ansiaisc-358-16-with-ansiaisc-358s1-18-andansiaisc-358s2-20/

ANSI/AISC 360-16 (2016). Specification for Structural Steel Buildings. American Institute of Steel Construction. Chicago, Illinois 60601-6204. EUA. Available in: https://www.aisc.org/products/publication/standards/specification-for-structural-steelbuildings-ansiaisc-360-162/

ATC-40 (1996). Seismic evaluation and retrofit of concrete buildings. Applied Technology Council, Redwood City, California, pp 346.

Carr A.J. (2002). Ruaumoko 2d y 3d Inelastic Dynamic Analysis Program (Version 2007) [Software]. University of Canterbury, Christchurch, New Zealand. http://www.civil.canterbury.ac.nz/ruaumoko 
CEN (2004). Eurocode 8: Design of structures for earthquake resistance. Part 1: general rules, seismic actions and rules for buildings. EN 1998-1:2004. Comité Européen de Normalisation, Brussels. 231 pp. Available in: https://www.wiley.com/en$\mathrm{gb} /$ Design+of+Steel+Structures+for+Buildings+in+Seismic+Areas:+Eurocode+8:+Design+of+Structures+for+Earthquake+Resista nce+Part+1:+General+Rules,+Seismic+Action+and+Rules+for+Buildings-p-9783433030103

Chopra A and Goel R. (1999). Capacity-demand-diagram methods based on inelastic design spectrum. Earthquake Spectra. 15(4):637-655. https://doi.org/10.1193/1.1586065

Chopra, A. K., and Goel, R. K. (2002). A modal pushover analysis procedure for estimating seismic demands for buildings. Earthquake Eng. Struct. Dyn, 31(3):561-582. https://doi.org/10.1002/eqe.144

Crisafulli, F. J., and Villafañe, E. (2002). Response and design spectra. Argentina: National University of Cuyo Faculty of Engineering.

CSI Structures (2018). SAP2000 Integrated Solution for Structural Analysis and Design. CSi Computers \& Structures, Inc. Structural and Earthquake Engineering Software. https://www.csiamerica.com/products/sap2000.html

Diaz S.A., Pujades L.G., Barbat A.H., Hidalgo-Leiva D.A. and Vargas Y.F. (2018a). Capacity, damage, and fragility models for steel buildings. A probabilistic approach. Bulletin of Earthquake Engineering. 16(1):1209-1243. https://doi.org/10.1007/s10518017-0237-0

Diaz S.A, Pujades L.G., Pinzón L.A. and Vargas Y.F. (2018b). An alternative approach to consider the effect of seismic directionality. Revista Ingeniería de Construcción. 33(3): 279-290. https://doi.org/10.4067/S0718-50732018000300279.

Diaz, S.A., Pujades, L. G., Barbat, A. H., Vargas, Y. F. and Hidalgo-Leiva, D. A. (2017). Energy damage index based on capacity and response spectra. Engineering Structures 152(1):424-436. https://doi.org/10.1016/j.engstruct.2017.09.019

ERN (Natural Irrigation Assessment). (2017). M8.2 earhquake damage of September 7, 2017. Recovered from https://ern.com.mx/web/

Fajfar P. (2000). A nonlinear analysis method for performance-based seismic design. Earthquake Spectra. 16(3):573-592. https://doi.org/10.1193/1.1586128

FEMA - HAZUS99 (2016). Multi-hazard loss estimation methodology. Earthquake model. Hazus ${ }^{\circledR}$ MH 2.1. Technical manual. 718 pp. Federal Emergency Management Agency. Washington D.C. Available at: https://www.fema.gov/hazus-mh-usertechnical-manuals.

Freeman S.A. (1998). The capacity spectrum method as a tool for seismic design. In: Proceedings of the 11th European Conference on Earthquake Engineering. Paris.

Georgios Baltzopoulos G., Baraschino R., Lervolino L., and Vamvatsikos D. (2017). SPO2FRAG: software for seismic fragility assessment based on static pushover. Bulletin of Earthquake Engineering. 15(1):4399-4425. https://doi.org/10.1007/s10518017-0145-3

Ibarra L.F., Medina R.A. and Krawinkler H. (2005). Hysteretic models that incorporate strength and stiffness deterioration. Earthquake Engineering \& Structural Dynamics. 34(12):1489-1511. https://doi.org/10.1002/eqe.495

Leelataviwat S., Saewon W. and Goel S.C. (2009). Application of energy balance concept in seismic evaluation of structures. Journal of Structural Engineering ASCE. 135(2):113-121. https://doi.org/10.1061/(ASCE)0733-9445(2009)135:2(113)

Lignos, D. G., and Krawinkler, H. (2011). Deterioration Modeling of Steel Components in Support of Collapse Prediction of Steel Moment Frames under Earthquake Loading. Journal of Structural Engineering ASCE, 137(11): 1291-1302.

https://doi.org/10.1061/(ASCE)ST.1943-541X.0000376

Lignos, D. G., and Krawinkler, H. (2013). Development and Utilization of Structural Component Databases for PerformanceBased Earthquake Engineering. Journal of Structural Engineering ASCE. 139(8):1382-1394. https://doi.org/10.1061/(ASCE)ST.1943-541X.0000646

MDOC-CFE (2015). Manual de diseño de obras civiles. Diseño por sismos. Comisión Nacional de Electricidad (CFE). México. 745 pp. Available in: https://www.gob.mx/ineel/articulos/manual-de-diseno-de-obras-civiles-diseno-por-sismo-logro-de-laingenieria-de-mexico

Mezzi M., Comodini F., Lucarelli M., Parducci, A. and Tomassoli E. (2006). Pseudo-energy response spectra for the evaluation of the seismic response from pushover analysis. In: First European Conference on Earthquake Engineering and Seismology. Geneva, Switzerland. Paper Number: 1183. 
Milutinovic Z. and Trendafiloski G. (2003). RISK-UE. An advanced approach to earthquake risk scenarios with applications to different European towns. WP04 Vulnerability of current buildings, pp. 111.

NTCDS-RCDF. (2017). Norma Técnica Complementaria para la Revisión de la Seguridad Estructural de las Edificaciones de la Ciudad de México. Gaceta Oficial del Gobierno de México, pp. 712. Available in:

https://www.google.com/url?sa=t\&source=web\&rct=j\&url=https://www.smig.org.mx/archivos/NTC2017/normas-tecnicascomplementarias-reglamento-construcciones-cdmx-

2017.pdf\&ved=2ahUKEwikrNf_i6nxAhXtQjABHfaeD3MQFjAAegQIBBAC\&usg=AOvVaw0cGCv1wQNw4fqY2islepqa

NEHRP (1994). Recommended Provisions for Seismic Regulations of New Buildings: Part I, Provisions, FEMA 222A. Washington, DC: National Earthquake Hazard Reduction Program: Federal Emergency Management Agency. Available in: https://www.wbdg.org/ffc/dhs/criteria/fema-222a

PEER/ATC 72-1 (2010). Modeling and acceptance criteria for seismic design and analysis of tall buildings. Applied Technology Council and Pacific Earthquake Engineering Research Center. 242 pp. Available in:

https://store.atcouncil.org/index.php?dispatch=products.view\&product_id=242

Pinzon, L.A., Vargas, Y.F., Pujades, L.G. and Diaz, S.A., (2020). A drift-correlated ground motion intensity measure: Application to steel frame buildings. Soil Dynamics and Earthquake Engineering. 132(1):106096.

https://doi.org/10.1016/j.soildyn.2020.106096

Pinzon, L.A., Diaz, S.A., Pujades, L.G. and Vargas, Y.F. (2021). An Efficient Method for Considering the Directionality Effect of Earthquakes on Structures. Journal of Earthquake Engineering. 25(9):1-31. https://doi.org/10.1080/13632469.2019.1597783

Pujades L.G., Vargas-Alzate Y.F., Barbat A.H. and González-Drigo J.R. (2015) Parametric model for capacity curves. Bulletin of Earthquake Engineering, 13(5):1347-1376. https://doi.org/10.1007/s10518-014-9670-5

PRODISIS. (2015). Software PRODISISv4.1. Instituto Nacional de Electricidad y Energías Limpias. Comisión Federal de Electricidad (INEEL-CFE). México. Available in: https://www2.ineel.mx/prodisis/es/prodisis.php

Satyarno, I. (2000). Adaptive pushover analysis for the seismic assessment of older reinforced concrete buildings. (Doctoral thesis). University of Canterbury Christchurch, New Zealand. https://doi.org/10.26021/1279

Vamvatsikos D. and Cornell C.A. (2002). Incremental dynamic analysis. Earthquake Engineering and Structural Dynamics. 31 (3):491-514. https://doi.org/10.1002/eqe.141

Vargas YF, Pujades LG, Barbat AH and Hurtado JE (2013). Capacity, fragility, and damage in reinforced concrete buildings: a probabilistic approach. Bulletin of Earthquake Engineering. 11(6):2007-2032. https://doi.org/10.1007/s10518-013-9468-x

Vargas YF, Pujades LG, Barbat AH and Hurtado JE (2019). An Efficient Methodology to Estimate Probabilistic Seismic Damage Curvles. Journal of Structural Engineering. 145(4). https://doi.org/10.1061/(ASCE)ST.1943-541X.0002290 